\title{
ROCHAS CLASTICAS DO PLANALTO DE POÇOS DE CALDAS
}

\author{
ALFREDO J. S. BJÖRNBERG
}

\section{ABSTRACT}

1 - Sandstone, siltstone and volcanic breccia occur in the region of Poços de Caldas occupying an interrupted strip near the contact alkaline rock and gneiss. On the west side of the alkaline area sandstone covers gneiss at an altitude of about 1580 meters. Outside this area no sediment of this type has yet been found.

2 - Sandstone and siltstone are generally well sorted fg.: $2,3,4,5$ and 6 . Coefficient of Sorting varies between 1,1 and 3,6 . The median diameter of sandstone grains vary between 0,10 millimeters and 0,54 millimeters. The majority has a diameter of about 0,3 millimeters.

3 - Roundness of sandstone and siltstone components were studied in size grades of 0,5 millimeter to 0,297 millimeter and 0,74 millimeter to 0,044 millimeter Roundness is similar in both fractions giving results always inferior to 0,5 and superior to 0,2 .

4 - Analysis of sedimentary composition gave the following mineral components:
$90 \%$ to $20 \%$
Quartz
$10 \%$ to $30 \%$
Feldspar
$1 \%$ to $80 \%$
Muscovite, bauerite and iron oxi- des. Its percentage is usualy lo- wer then 30 . 
5 - Heavy minerals are usualy $1 \%$ of the total composition or even less. Zircon is the most common heavy mineral in all samples. In decreasing order of frequency are the following minerals:

Anatase, tourmaline, rutile, garnet, monazite, hornblende, apatite, and corundum.

The greatest quantity and variability of heavy minerals appears in sedimentary rocks of Águas da Prata and Serra do Mirante at the south-western border of the alkaline complex (Table 4) Moreover, leucoxene is very common as sandstone ciment.

6 - Frosted or dull sandstone grains are very common. As they are poorly rounded, dullness was considered as provoqued by etching.

7 -- The greatest thikness of sediment is of the order of 90 meters in Aguas da Prata. Thirty meters are of sandstone at the upper part and 60 meters of siltstone at the lower part alternating with sandstone layers. Siltstones dip never exceeds 20 degrees. Sandstones parallel or cross bedding dip does not exceed 30 degrees. In some places sandstone passes gradually to arkose, sometimes with torrential structure, sometimes with pebble intercalations. On the top of the Poços de Caldas plateau siltstone is lacking and sandstone is not so thick as on the outside region. Plateau sandstone is cut by alkaline intrusions and at certains points by basic intrusions (diabase) Sandstone intercalations in siltstone show two different types of sedimentation: one of aeolian or fluvial nature and another of lacustrine nature.

8 - Age determination of these sediments was not possible because no fossils were found. Correlation on lithologic basis was established between these sediments and others of known age. Comparison was tried between these sediments and fluvioglacial, Bauru and Botucatu sandstones. Some similarities between Poços de Caldas sandstone and Botucatu sandstone (triassic) were found, considering texture and heavy minerals, so correlation between these two was established. 
The hypothesis that Poços de Caldas sandstone belongs to Bauru series is out of question, at least in Aguas da Prata and north of Andradas because there it is cutt by diabase.

9 - All fragmentary rocks directly involved in the alkaline volcanism were considered as brecciae. Theses rocks follow internally the encircling mountains of the plateau. They are chiefly of two different types:

a - Detritic; b - Magmatic

a $\rightarrow$ Detritic: This rock outcrops from Aguas da Prata up to Poços de Caldas and isolatedly at north of Andradas at a piace called Pinheirinho farm. The fragments have a chaotic distribution in a fine brown or greenish blue aphanitic mass. The most common fragments are of altered diabase and in minor quantity quartzite, lava and gneiss. Quartz and feldspar are the most common mineral fragments generaly corroded and substituted by calcite.

Calcite, hematite and aegirite are very common minerals of the matrix, and in minor quantity leucoxene, apatite and biotite. These rocks show bedding in a few outcrops in Cascata and Poços de Caldas (near Rio das Antas) There is still another type of pyroclastic rock, very finely grained, containing decomposed vitreous fragments and brown mass, at the base of Serra do Paiol and in the center of the plateau irı a small outcrop.

$\mathrm{b}$ - Magmatic: The matrix is tinguaitic containing fragments of pyroxenic rock, lava, sandstone, and foyaite, near Poços de Caldas. On the west boundary of the plateau on the Serra do Paiol, appears the same kind of rock. Its texture is coarser and the fragments are the same as in the former It outcrops in an area of aproximately five square kilometers, having at most ten meters thickness.

10 - Origin: Type a breccia is primary detritic and later on modified by movement and solution percolations. Several clues allow this conclusion. They are the following: 
a - Great quantity of well rounded sandgrains in the matrix.

$\mathrm{b}$ - Bedding of these rocks in some expositions.

c - Ideomorphic sodic pyroxene ocurring in the matrix, sometimes forming amigdales or needles.

$\mathrm{d}$ - Albitization of diabasic feldspars and sandstone grains corrosion.

e - Curved shaped twinning of calcite and mortar texture of some fragments.

Type b, brecciae is magmatic for the matrix is of igneous rock.

11 - Brecciae are younger than sandstone and diabase, as they contain fragments of these two types of rock. They must be older than the last alkaline eruption as they are cut by dykes of tinguaite.

12 - Sandstone on the plateau at 1300 meters altitude in comparison to the same rock on the outside at 820 meters hight, shows that the alkaline intrusion has probably risen.

13 - This must have been accomplished by faulting in block movement that kept more or less the same level all the time. This conclusions is allowed by the following:

a - The sandstones either on the inside or on the outside of the plateau have a very small dip.

b - Inside the plateau, the sandstone follows the alkaline circle at more or less the same level (1300 meters altitude)

c - The contact of alkaline rock and gneiss is, when visible, also aproximately vertical.

14 - The following clues indicate a small subsidence of plateaus central part:

a - Dipping of sandstone is generally to the center of the plateau. 
b - Sandstone occupies an altitude of 1580 meters on top of gneiss on the outside of the plateau (Serra do Mirante) On the inside its altitude is of 1300 meters aproximately

c - On the center of the plateau pyroclastic rock is at the same level as sandstone occupying the internal border This shows either a small subsidence, or a long period of volcanism permitting after erosion the deposition of pyroclastic rock at the same level as sandstone.

15 - Considering all observations and evidence, schematic representation of geological events was tried on the drawings of fig. 12, 13, 14, 15 The first, shows the first stage, anterior to the intrusion. Sandstone was occupying all the region. Near the mountains, in the desert, siltstone and clay were beeing deposited. The second drawing 13, shows intrusion and volcanism. The third 14 , shows a phase of subsidence. The drawing is exagerated. The fourth figure 15 , shows schematically the actual form of the plateau, after a long phase of erosion.

\section{INTRODUÇÃO}

O escopo principal do presente trabalho é o estudo das rochas clásticas do planalto de Poços de Caldas, sủl do Estado de Minas Gerais, enquadrado nas longitudes de $46^{\prime}$ e $47^{\circ} \mathrm{W}$ (Greenwich) e nas latitudes de $21^{\circ}$ e $22^{\circ} \mathrm{S}$. A mapeação do referido planalto foi executada pelos Drs. José Moacir V Coutinho e Reinholt Ellert com a colaboraçāo do autor Os resultados dêsse trabalho figuram no mapa anexo.

O planalto de Poços de Caldas é uma das maiores ocorrências de rochas alcalinas do globo. Situa-se junto aos contrafortes da serra da Mantiqueira, entre as cabeceiras dos rios Pardo e Mogiguassu. E' rodeado por uma cinta de rochas sedimentares clásticas. Os sedimentos são muito importantes, auxiliando o reconhecimento e estudo das estruturas da região. Assim, as amplitudes e orientação de certos deslocamentos nas eruptivas puderam ser conhecidos, graças aos movimentos que interessarain os dois tipos de rochas. 
Foram também estudadas as rochas clásticas diretamente ligadas, quanto à origem, ac vulcanismo. São representadas por ıchas piroclásticas pròpriamente ditas, isto é, por rochas exjelidas por vulcões e por brechas associadas às intrusões alcalınas. Este último tipo compreende as rochas primàriamente pi roclásticas, ígneas, ou sedimentares, que sofreram movimento, injeção, ou percolação de material ígneo. O estudo das

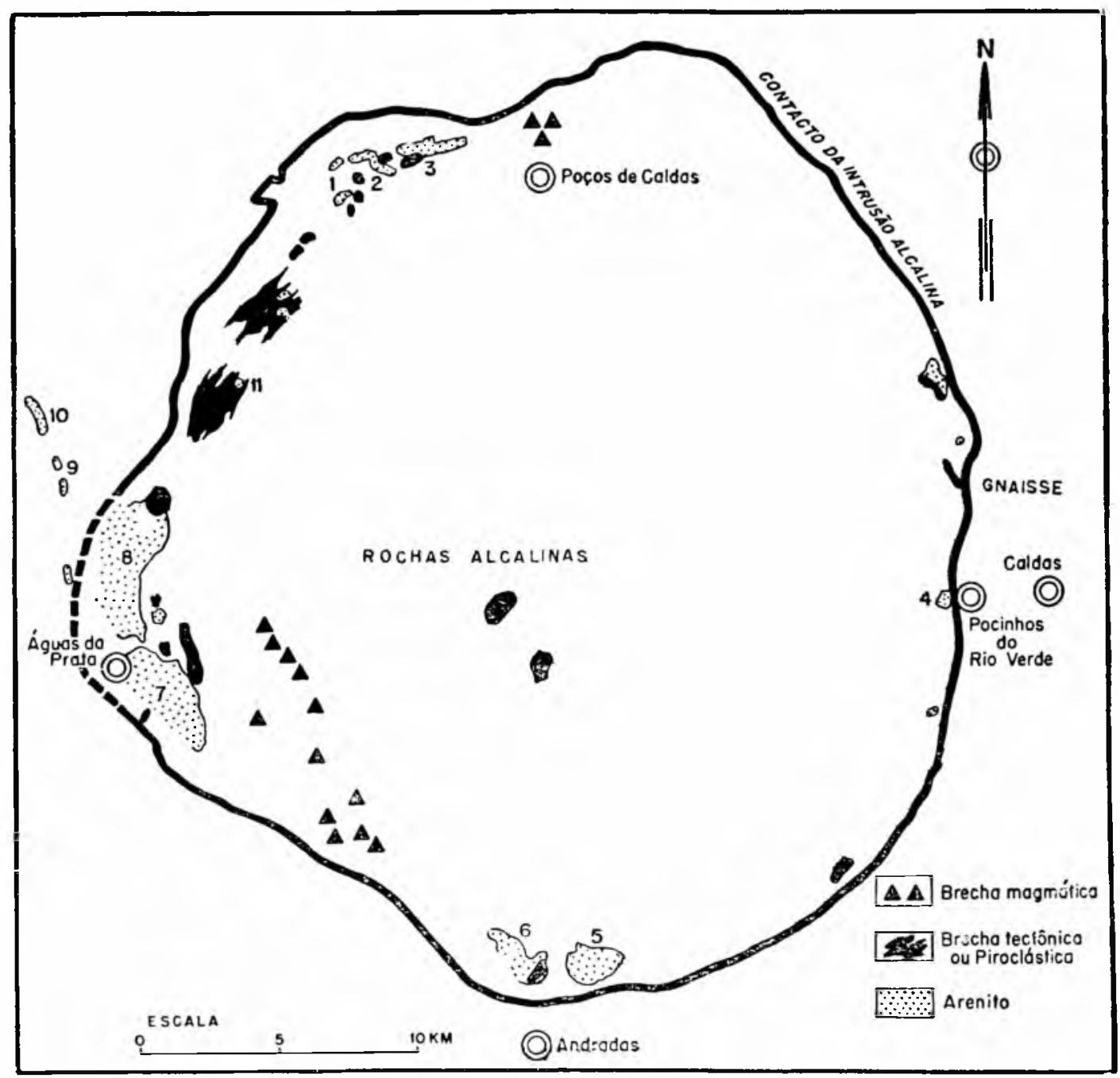

rig. 1 .

brechas é de importância capital para o conhecimento das condições geológicas que existiram na região. A figura 1, mostra um mapa da mesma, em que são representados os con- 
tactos das rochas alcalinas com a encaixante, as rochas clásticas e os pontos numerados de coleta do arenito. No mapa, são marcadas brechas magmáticas, ou material fragmentário englobado por rocha ígnea, das brechas piroclásticas, isto é, provenientes da ejecção e deposição de material vulcânico. O mapa dá uma idéia do tamanho da área estudada.

Graças à beleza da paisagem, ao ótimo clima $e$ às propriedades medicinais das águas do planalto, serviu êle de atrativo a numerosos visitantes.

Derby (16), no fim do século passado, foi o primeiro geólogo que Examinou essa localidade. Êsse notável naturalista teve sua atenção chamada para o arenito ali existente, extremamente branco, fino e fraturado, de aspecto metamórfico. Relacionou-o a sedimentos carboníferos, por ter encontrado, entre suas camadas, intercalaçōes de folhelho. Contudo, não encontrou fósseis que estabelecessem, corretamente, a idade dessas camadas. Constatou Derby. ainda, com referêncıa às rochas clásticas, tufo capeado por arenito e intrusões alcalinas no sedimento. Cinqüenta anos depois, novas observações sôbre essas rochas foram feitas por Barbosa (3, p. 33) Êste autor situa os folhelhos, nas formações Estrada Nova e Kio do Rastro, atribuindo o metamorfismo de tais rochas à infiuência da intrusão alcalina nas mesmas. O arenito é identificado ao microscópio por aquêle autor como Botucatu. Mais recentemente, temos o trabalho de Freitas (18, pp. 26-37), inciuindo os folhelhos na série Passa Dois, transgressiva sôbre o arqueano na região de Poços de Caldas. Considera êsse autor o arenito como pertencente à série São Bento, transgressivo em maior escala que os sedimentos da série anterior, ambos, em alguns pontos do planalto, muito metamorfoseados. Sugere, como interpretação da geologia um único vulcanismo e snerguimento das estruturas sedimentares pelo magma alcalino, que as separou dêste modo, do embasamento cristalino Em 1948, Barbosa (4, pp. 235-237) apresenta outro trabalho, contestando o ponto de vista de Freitas, afirmando ter havido cluas atividades do magma alcalino na região de Poços de Caldas. A primeira, plutônica, anterior ao permiano, que depois 
de desgastada teria servido como base de deposição ao sedimento. A segunda, vulcânica, extrusiva, teria agido em várias fases, metamorfizando e perturbando os arenitos e folhelhos. Outras observações permitiram ao autor citado explicar a sitıação elevada dos arenitos, por um processo de soerguimento epirogênico moderno. Freitas (19, pp. 85-90) volta ao assunto em 1951, refutando as idéias de Barbosa, porém não oferece novos dados sôbre as rochas clásticas. O último trabalho que se refere aos mesmos sedimentos é o de Branco, em 1956 (10, pp. 9-11) Esste autor verificou a semelhança na composição dos arenitos da Serra do Mirante. vizinha ao planalto, com o arenito Botucatu. Acha também que os blocos de arenito flutuaram sôbre o magma, no planalto, esposando a idéia de Freitas. Com referência às brechas estudou, do ponto de vista petrográfico, várias secções delgadas. No campo, teve oportunidade de constatar intrusões alcalinas, em aglomerado vulcânico, observações essas que o levaram a acreditar em mais de uma fase eruptiva.

Devo meus agradecimentos ao nosso mestre Professor Dr. Viktor Leinz, por seus conselhos, ensinamentos e orientação; aos Drs. Alceu F. Barbosa e Rui O. de Freitas, pelo auxílio técnico aos meus colegas e amigos Drs. José Moacir V Coutinho e Reinholt Ellert, pelas críticas construtivas, cooperação. determinaçōes petrográficas etc.; ao Dr. Elisiário Távora, várias determinaçōes mineralógicas, ao Conselho Nacional de Pesquisas, o auxílio material. O autor agradece a todos que o ajudaram a executar êste trabalho.

\section{ARENITOS E SILTETOS}

Coleta de sedimentos: Procuramos coletar amostras de sedimentos de todos os tipos que apresentassem diferenças físicas, litológicas e de estrutura, que não tivessem sofrido metamorfismo de contacto ou recristalização. Esta norma foi obedecida pelas seguintes razões:

a) As rochas sedimentares metamorfoseadas mostram, freqü:ntemente, deformações plásticas ou recristalização de grãos, 
cujos graus de arredondamento são diferentes dos apresentados no sedimento original.

b) A desagregação das mesmas, para serem peneiradas, provoca fraturamento e granulação artificial em relação à rocha original.

c) Para facilitar a comparação dêste trabalho com os de outros autores. O estudo destas rochas metamorfoseadas em secção delgada não foi feito porque, usando êsse método, fica suprimida uma dimensão, resultando daí dados imprecisos.

Análise mecânica: Depois de coletado, o material foi desagregado a mão. As frações de cada amostra, menores que 43 riicrons, foram separadas por decantação. O material resiante foi secado em estufa a $100^{\circ} \mathrm{C}$ aproximadamente. Foram examinados grãos aglutinados das diversas frações para o recálculo granulométrico. Para não produzir um fraturamento artificial dos aglutinados, por uma desagregação mais enérgica, preferimos determinar ao microscópio, a freqüência dos mesmos e, nessa base, recalcular a granulometria. A análise granulométrica do siltito ou da fraçāo fina do arenito foi feita pelo processo de decantação em água, usando-se como defloculante oxalato de sódio. A suspensāo decantada foi filtrada e seu pêso determinado após secagem em estufa. O método de decantação não satisfaz plenamerite por duas razões:

1 - Partículas pequenas têm sua marcha de queda normal modificada no fluído, graças aos movimentos conveccionais do meio líquido, dificultando o contrôle da sedimentação.

2 - Outra razão é o não saber se a desagregação foi suficiente para separar os compostos primários do material. Entretanto, assim mesmo foi usado êsse método, por ser suficientemente aproximado e para não haver quebra do processamento, que complicaria a marcha normal dos trabalhos de laboratório A análise mecânica dos sedimentos arenosos deu tipos diversos de curvas cumulativas, que foram representadas nas figuras $2,3,4,5$ e 6 . Nas abcissas, são marcados os diâmetros 
dos grãos em milímetros. Nas ordenadas, a porcentagem em pêso. Nas curvas cumulativas, assim como nas tabelas que se seguem, são dados os números das amostras correspondentes à numeração do mapa da fig. 1, nos pontos em que foram coletadas. As letras indicam os tipos diferentes de amostras obtidas nos afloramentos indicados pelos números. Maneira simples de resumir os resultados estatísticos dessa análise está na obtenção dos quartís, mediana e coeficientes de seleção. Os dois primeiros, $Q_{3}$ e $Q_{1}$, podem ser obtidos, gràficamente, como pre-

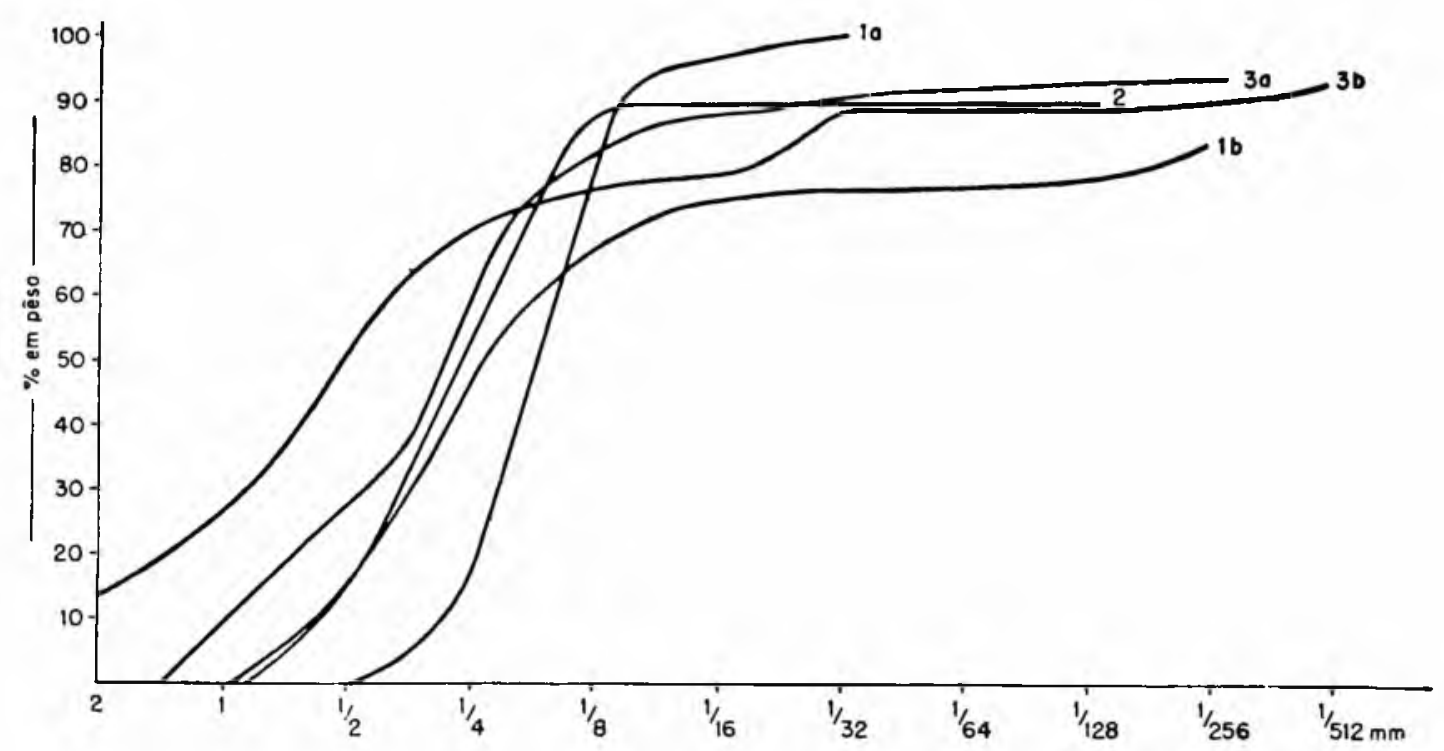

F:g. 2 .

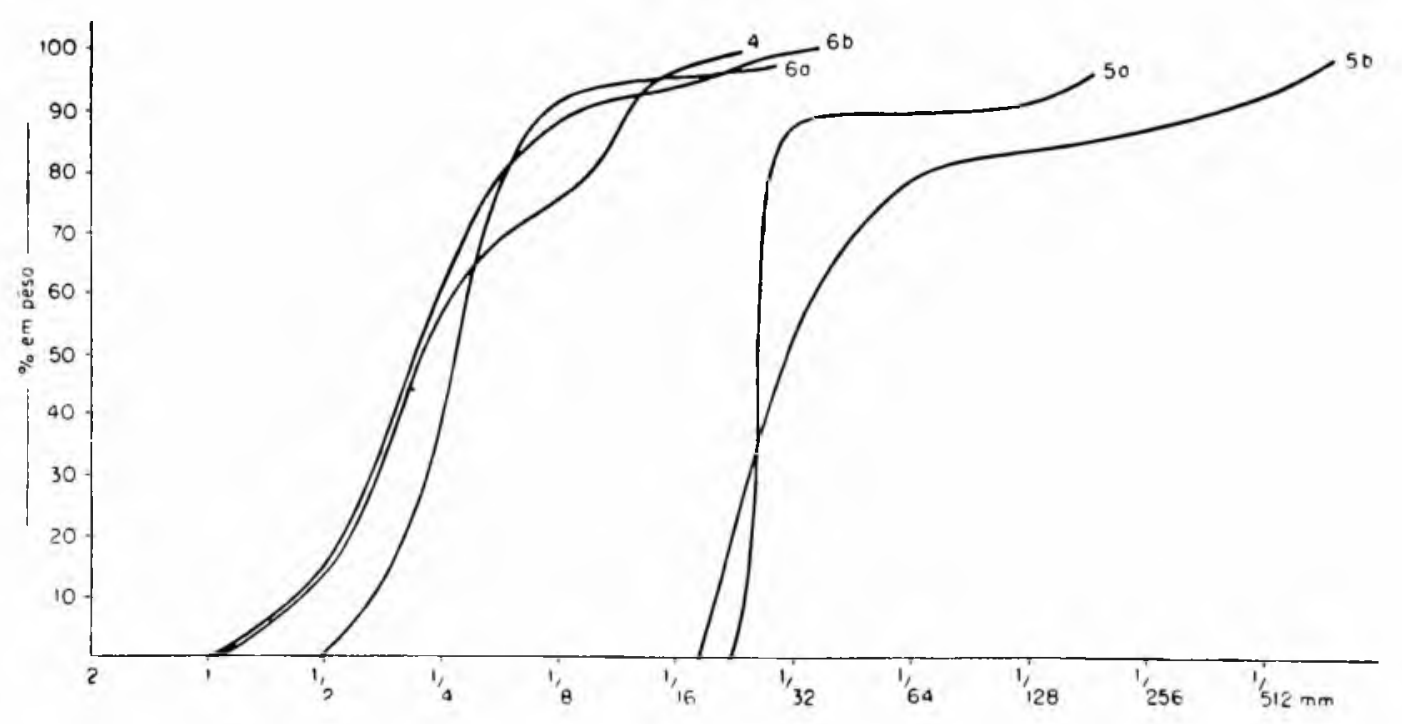

Fig. 3 . 


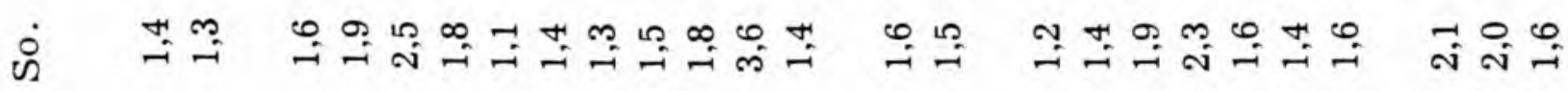

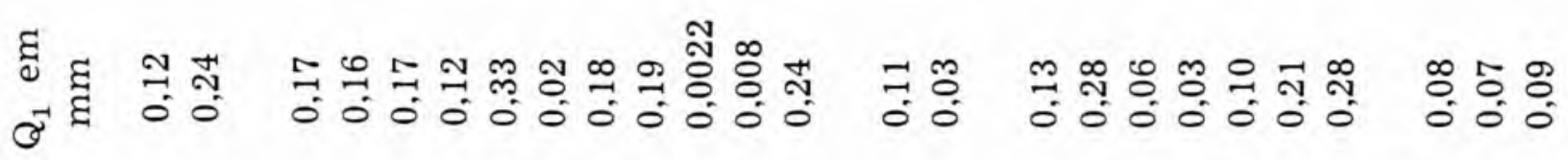

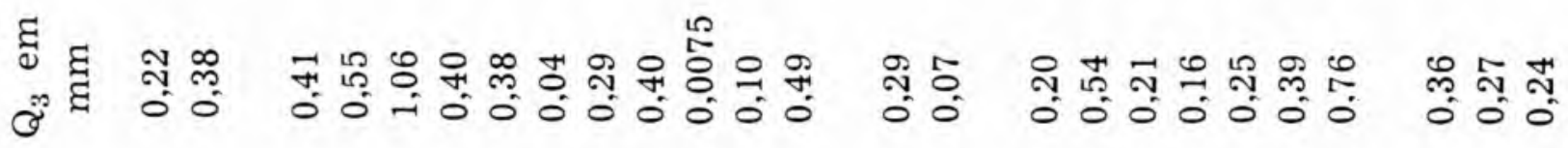

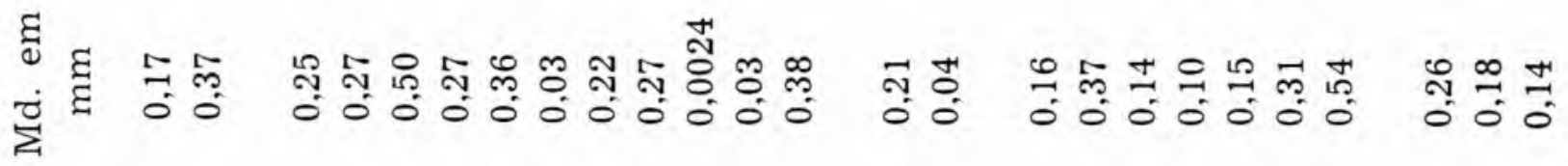

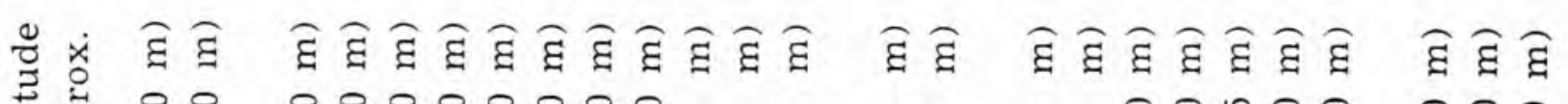

- 至范

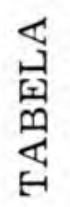

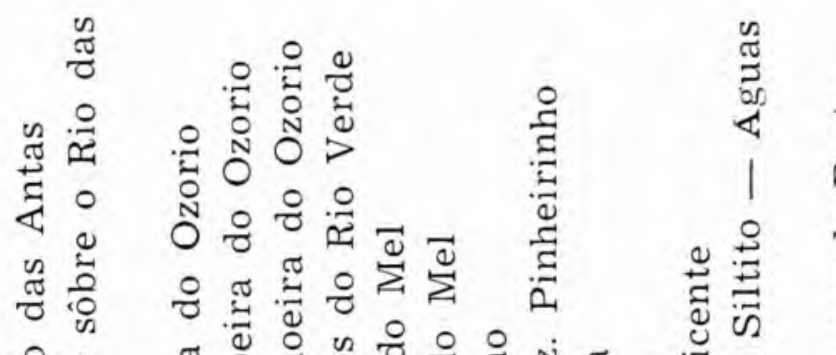

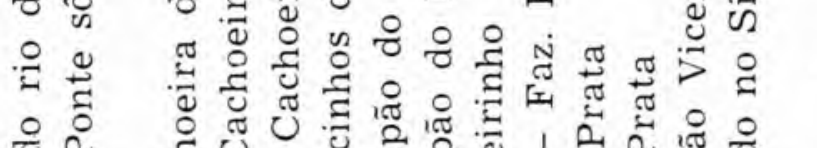

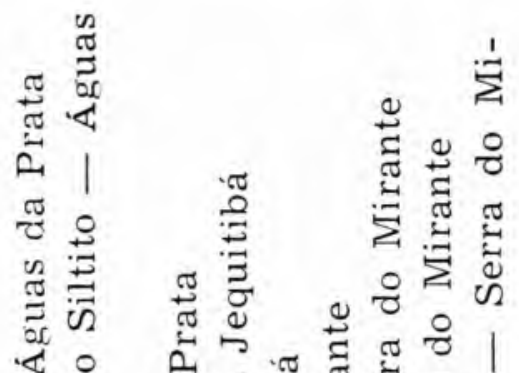

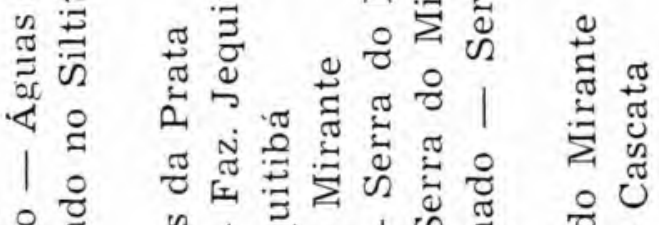

घี 1 ठ 1 ।

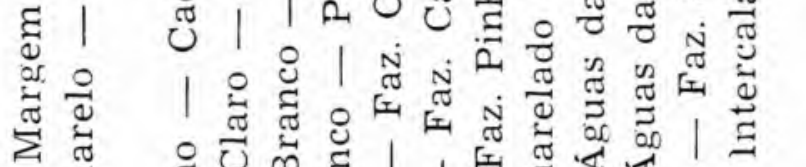

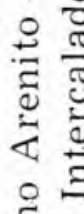

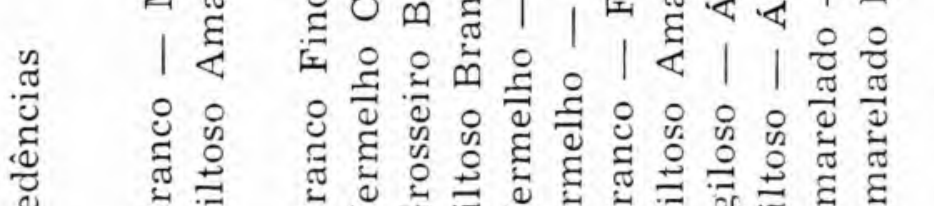

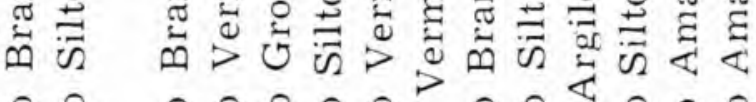

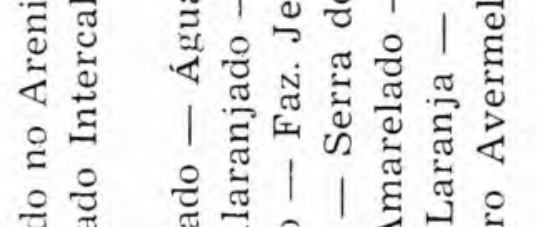

\%

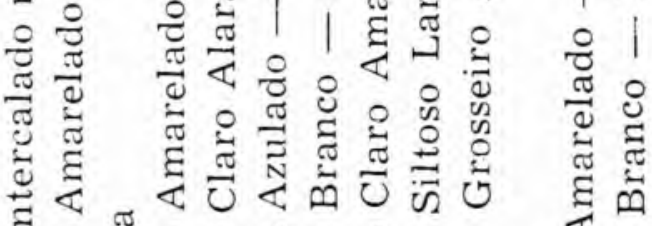

क

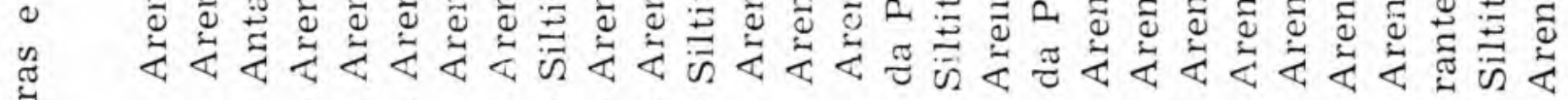

1

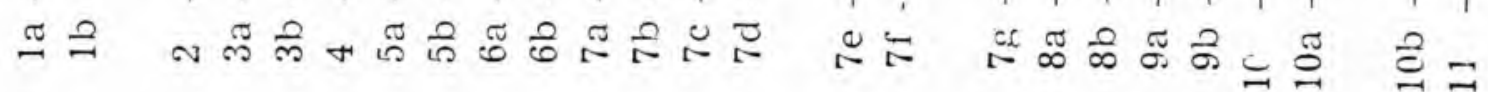




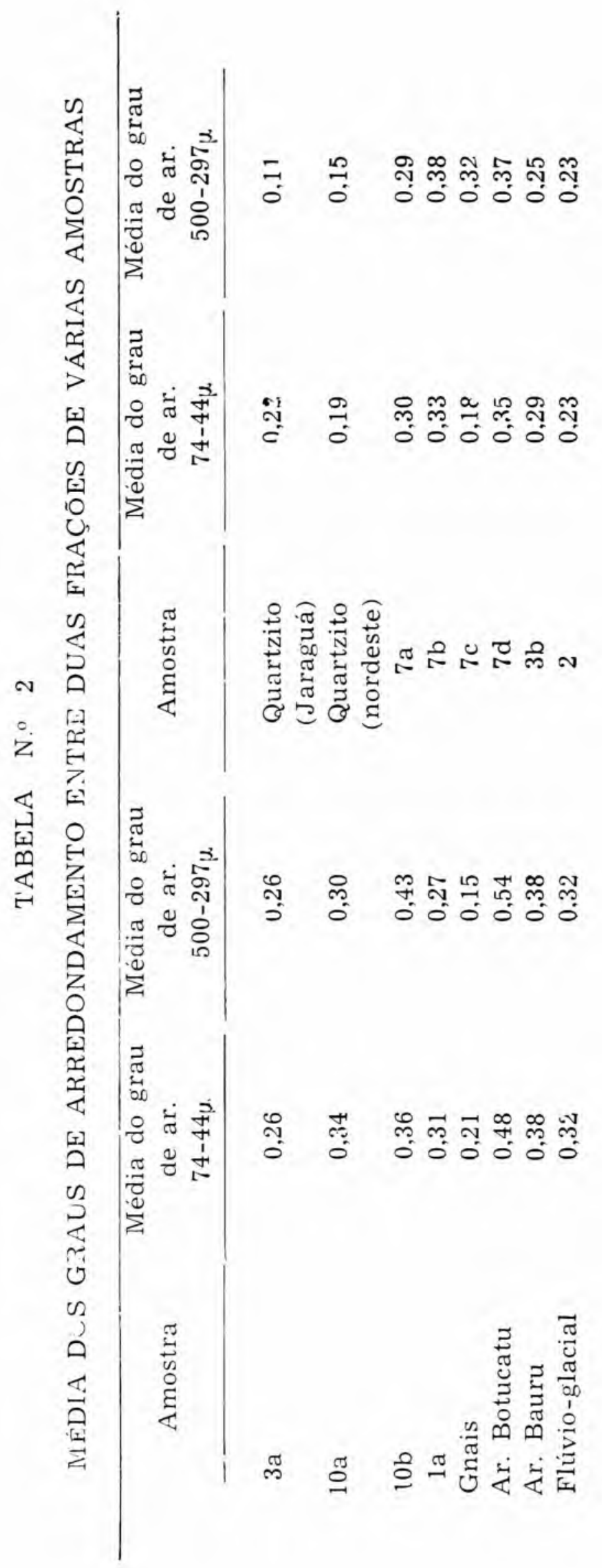




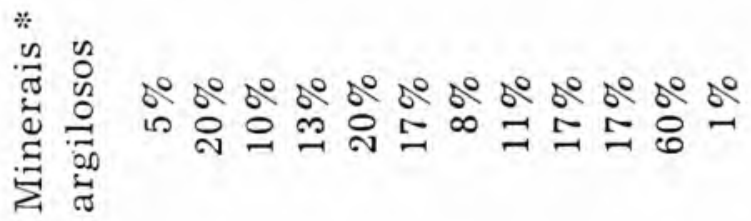

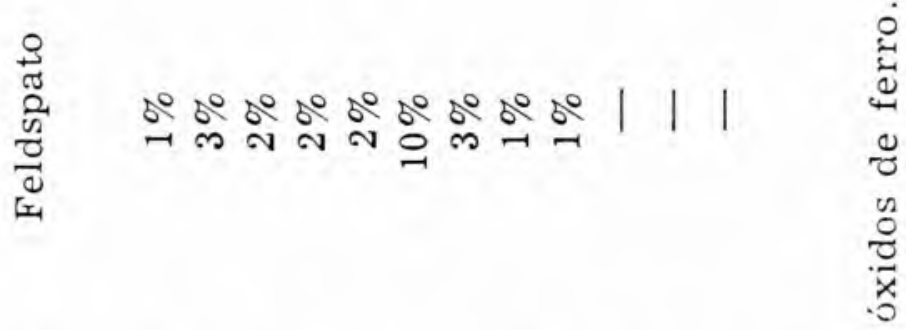

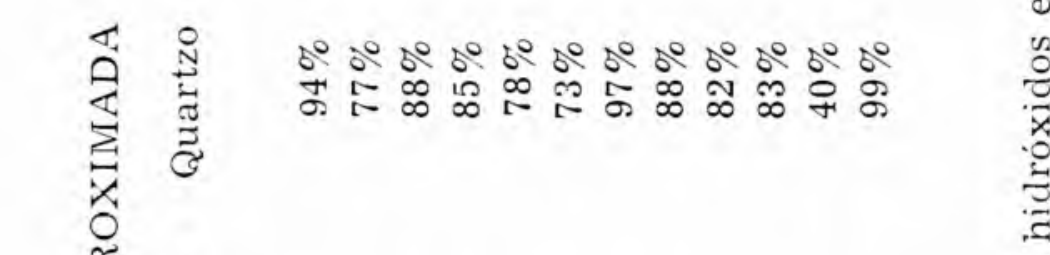

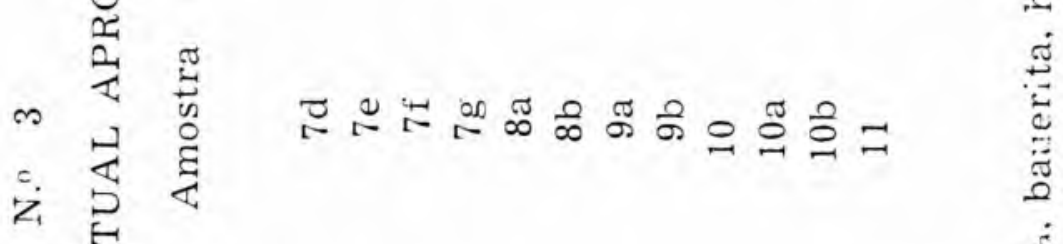

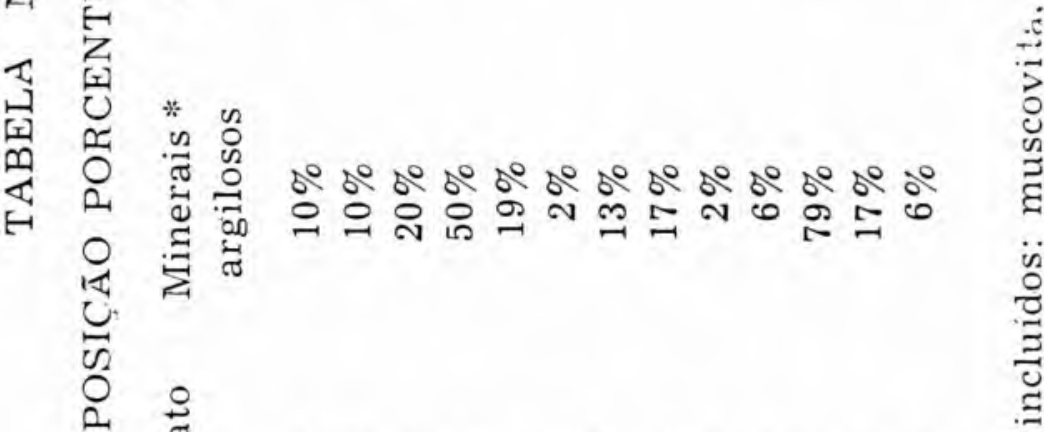

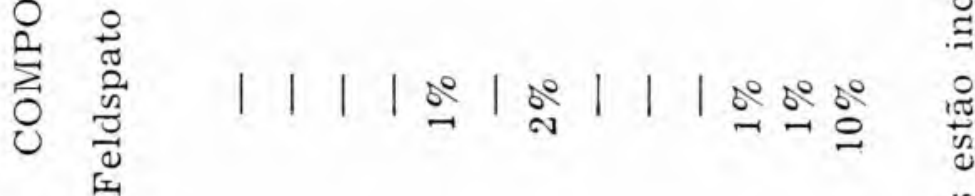

ำ สี

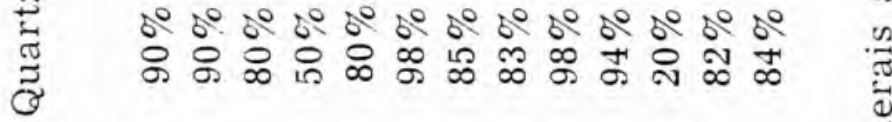
㺃 


$$
\begin{aligned}
& \text { 营 }|1||||||| \mid \text { | } \\
& \underset{\mathbb{2}}{\mathbb{2}}
\end{aligned}
$$

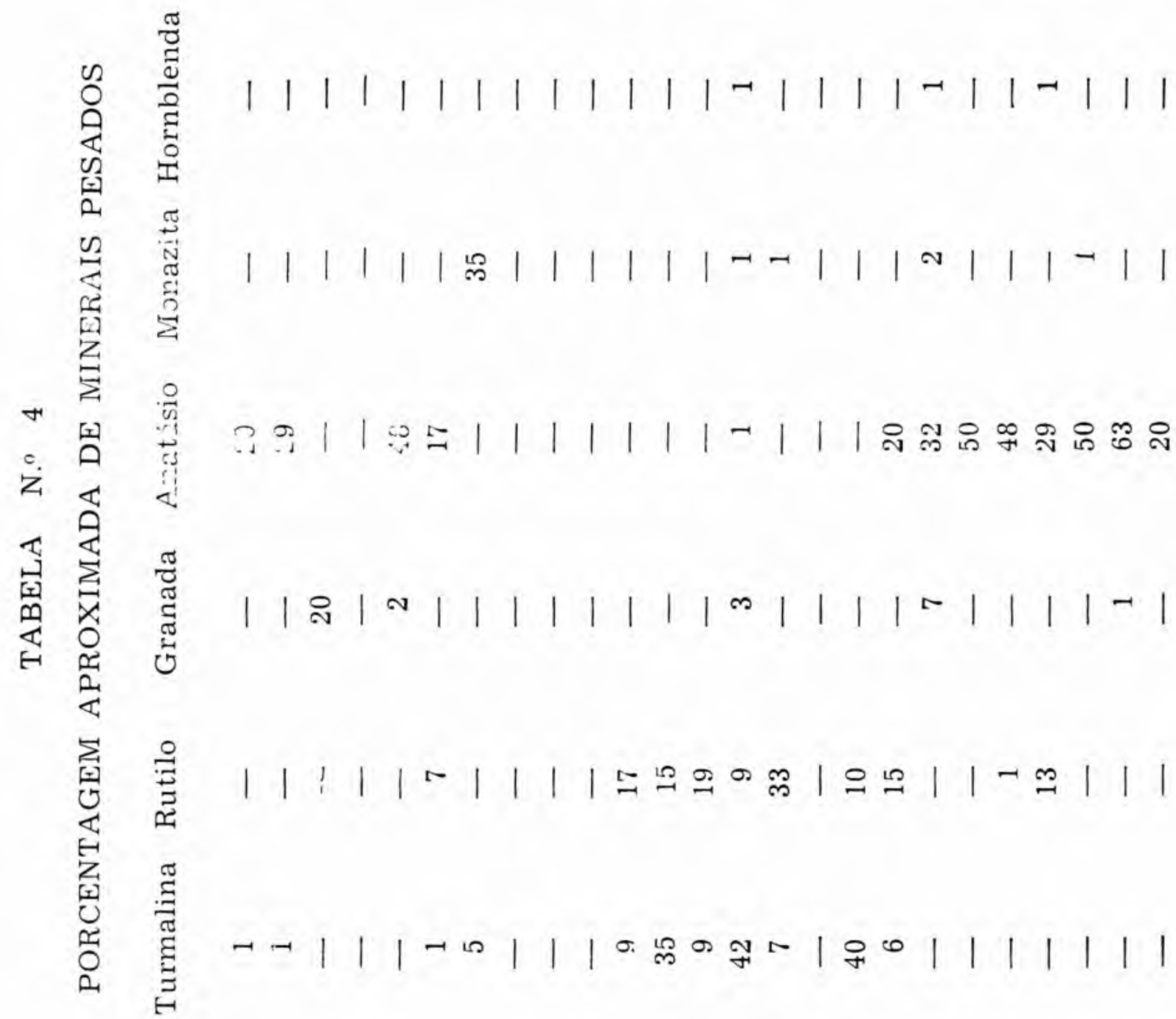

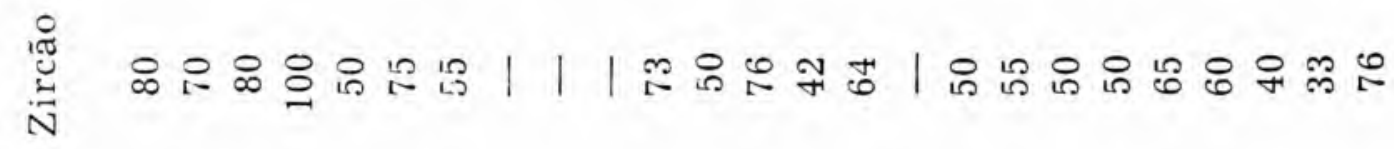

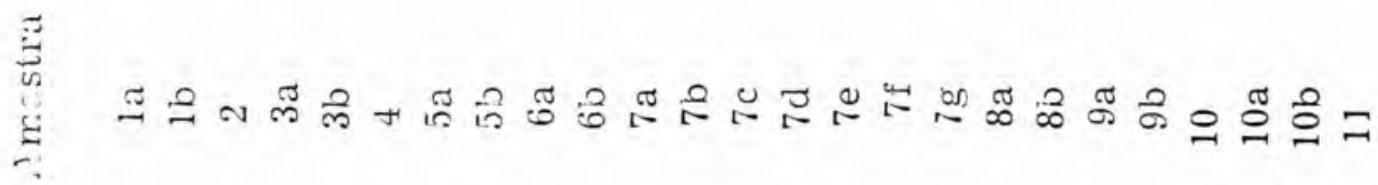


conizam Krumbein e Sloss (22, p. 73), e o último, peląsseguinte fórmula: $\mathrm{SO}=\sqrt{\frac{\mathrm{Q}_{3}}{\mathrm{Q}_{\mathbf{1}}}} \mathrm{Na}$ tabela 1 são dados os valores da mediana, quartís e grau de seleção aproximados das diferentes amostras. A mediana e o coeficiente de seleção parecem dar indicações sôbre o processo de formação dos sedimentos clásticos. Como se vê na tabela 1, há uma grande diferença nos valores das diferentes medianas. Quanto aos quartís, há apro-

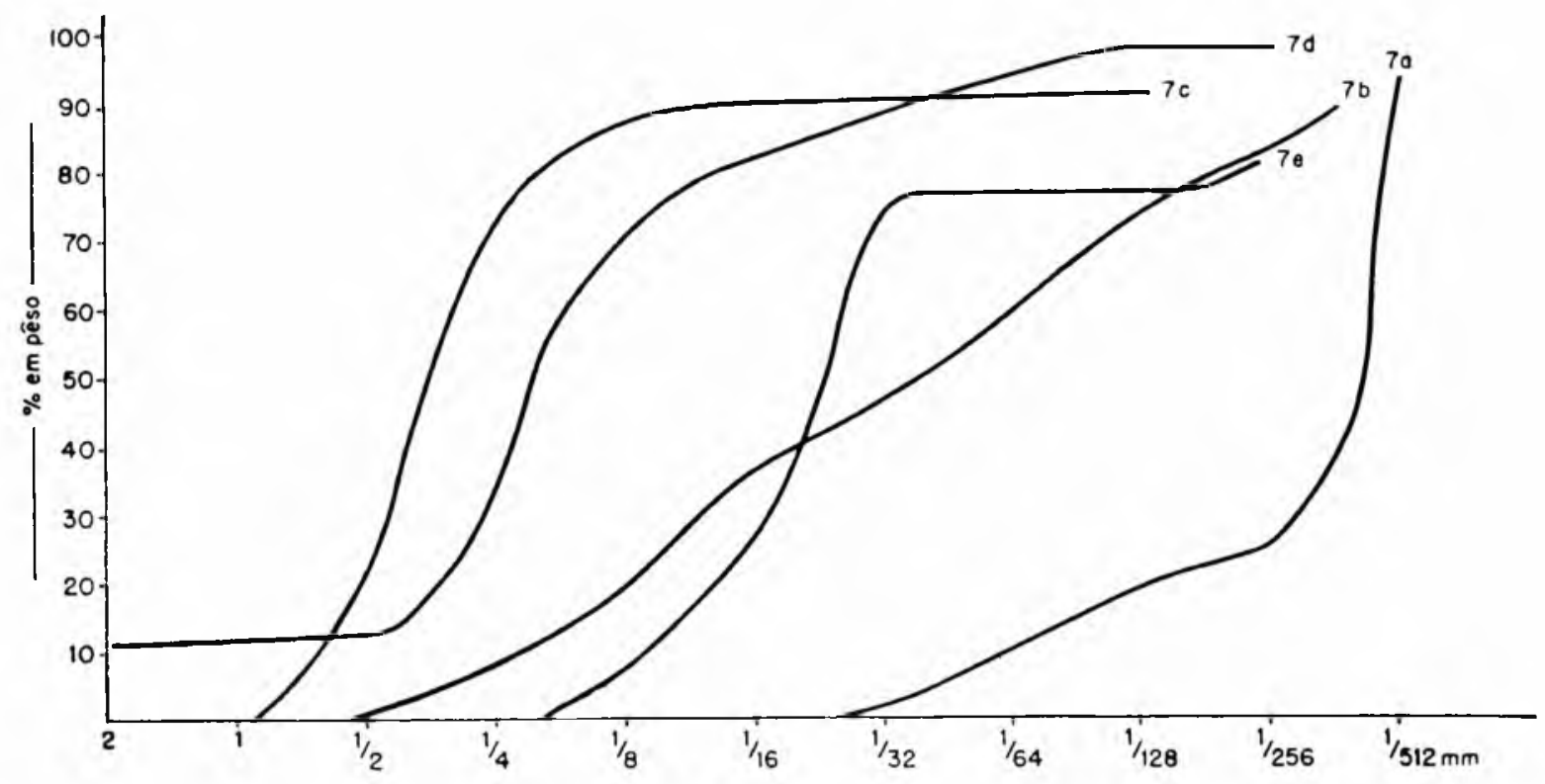

Fig. 4 .

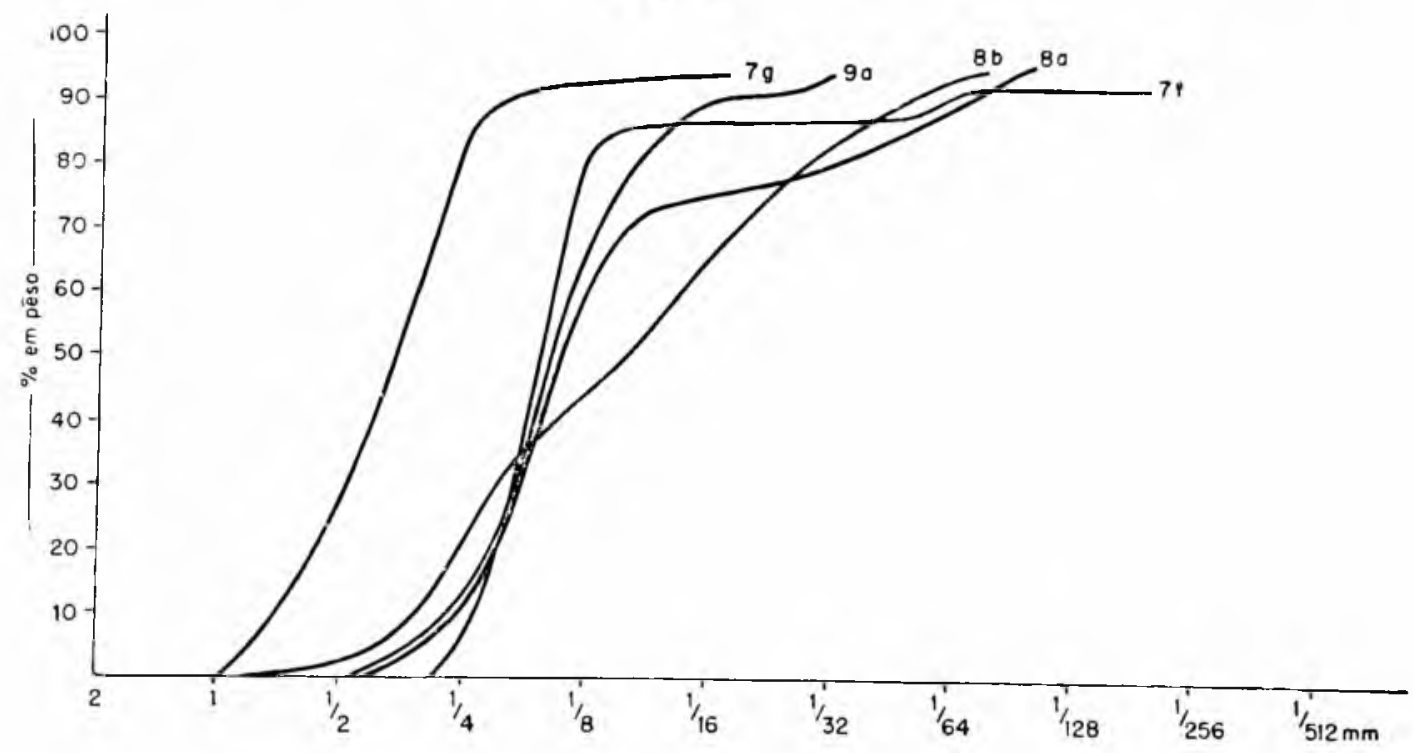

Fig. 5 . 
:imação ora de uma ora de outro, em relação à mediana das diversas amostras. Segundo Krumbein e Sloss (22, p. 75) êsses ciados parecem indicar mudanças na competência do agente erosivo. Ainda segundo os mesmos autores, grandes discrepâncras do grau de seleção devem indicar condições variadas de iransporte. Os dados texturais $Q_{3}$ e $Q_{1}$ permitiram fazer uma classificação de iôdas as amostras de acôrdo com Pettijohn (28, p. 27) Segundo essa classificação, tabela 1, as amostras $1 \mathrm{~b}, 4,6 \mathrm{~b}, 7 \mathrm{~b}$ e 10 poderiam ser chamadas de arenito siltoso; as amostras $5 \mathrm{~b}$, 7e e $10 \mathrm{~b}$ chamar-se-iam siltitos; a amostra $7 \mathrm{a}$ seria um siltito argiloso e tôdas as restantes amostras enquadrar-seiam entre os arenitos.

Certas amostras rudáceas não permitiram análise mecânica normal, pelo fato de conterem grandes ou pequenos fragmen-

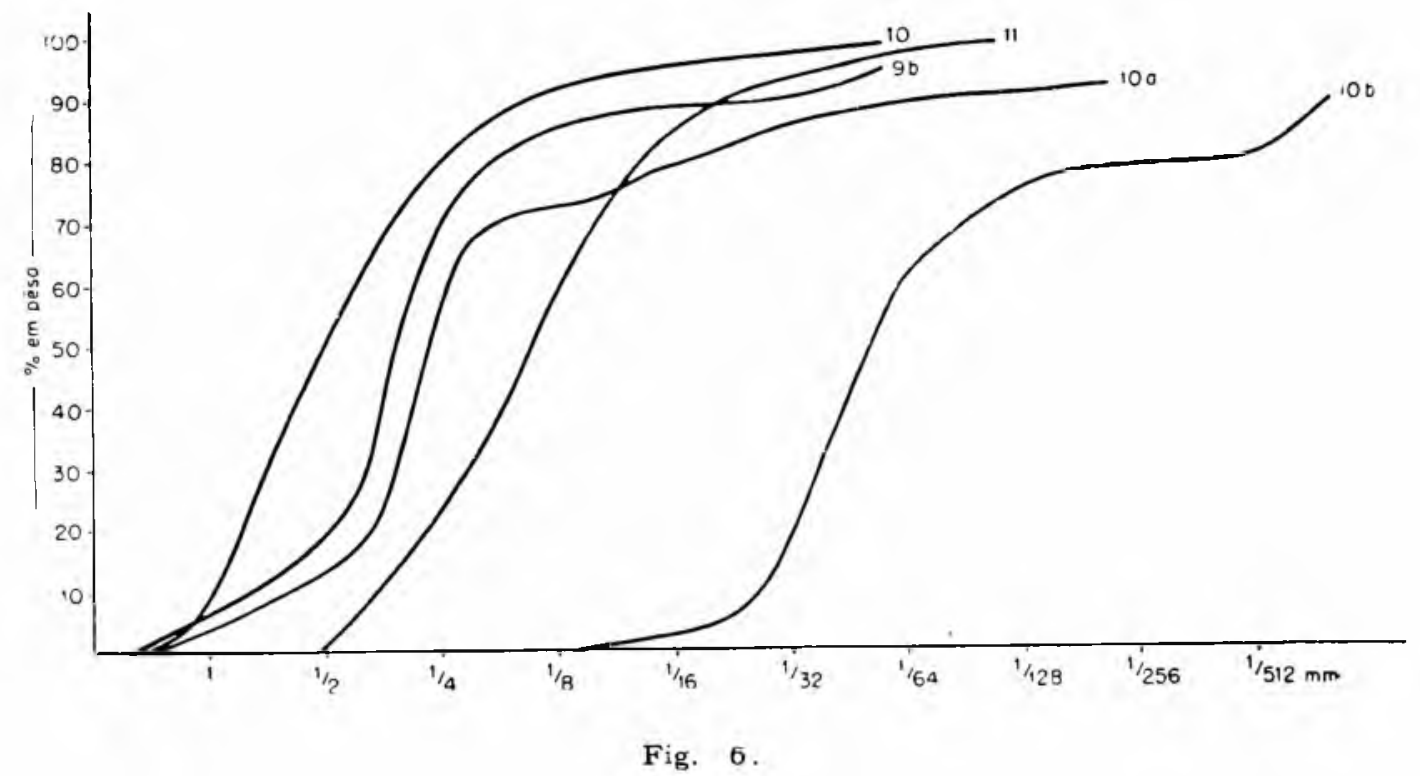

tos de feldspato decomposto, ou rocha decomposta. Foram elas estudadas com auxílio da lupa binocular

Secção dos componentes: As partículas componentes dos sedimentos foram classificadas, quanto à forma, segundo o grau de arredondamento Esta é uma relação entre a média dos raios das angulosidades e o raio do máximo círculo inscrito. As secções dos grãos quartzosos das diversas amostras foram desenhadas por meio de "câmara clara" adaptada ao microscópio. Se- 
guindo-se método de Wadlel (36), foi possível fazer a determinação do grau de arredondamento para 40 grãos de cada fra५ão. Tomando por base o princípio de que o arredondamento de areias e seixos quartzosos é função da distância transportada, do tamanho dos elementos e do meio transportador, resolvemos comparar, na mesma rocha, os graus de arredondamento dos grãos de duas frações distintas, isto é, 74 a 105 e 297 a 500 miicrons. O meio não só influirá no modo de deslocamento, como também no tipo de impacto que os grãos em transporte sofrerão. Assim, no meio aquoso, o transporte em suspensão é facilitado pelo fato da água ter maior densidade que o ar e, ainda, por ter essa densidade aumentada, quando rica em impurezas tais como argila, ou sais. O impacto das partículas entre si é amortecido no ambiente aquoso, devido ter a água maior viscosidade que o ar Assim, pode-se determinar, às vêzes, o grau de maturidade de certos sedimentos arenosos pela relação; tamanho e arredondamento. Pode-se também determinar dentro de certos limites o ambiente em que se formou o sedimento, comparando os graus de arredondamento entre grãos grosseiros e finos de uma amestra. Com o fito de se estabelecer essa comparação, foram feitas as seguintes determinações do grau de arredondamento: dez de arenitos do planalto de Poços de Caldas, uma do arenito Botucatu (provàvelmente eólico), uma do arenito Bauru, uma de sedimento considerado flúvio-glacial, duas de quartzito decomposto não transportado, uma de grãos quartzosos de gnais decomposto rão transportado. Os arenitos Botucatu e Bauru, foram coletados em São Carlos (Estado de São Paulo) O gnais e uma das amostras de quartzito foram coletadas nos arredores de São Paulo. A outra amostra de quartzito foi coletada na Serra Jacobina (Bahia) O arenito flúvio-glacial foi coletado em Campunas (Estado de São Paulo) A tabela 2 apresenta os resultados dessa análise. Foram feitas outras determinações do grau ce arredondamento em amostras do planalto de Poços de Caldas, porém para estas se usou um método mais expedito, de Russel e Taylor (30) modificado por Pettijohn (28. pp. 52-54), 
menos preciso. Em resumo os resultados desta última foram os seguintes:

1 - Em cada amostra de Poços de Caldas, nenhuma das duas frações apresentou grãos, cujas médias em grau de arredondamento ultrapassou o valor de 0,5 .

2 - Em geral, as médias em grau de arredondamento correspondentes à fração grosseira e fina tiveram valores iguais ou riuito próximos.

De tudo o que foi exposto, em conjunto, pode-se concluir que:

a) No arenito formado em ambiente provàvelmente eólico, os graus de arredondamento são altos para o material das; duas frações. Os grãos de areia da fração grosseira são melhor arredondados que os da fração fina.

b) Nessas amostras de arenito formado em ambiente aquoso, os graus de arredondamento correspondentes às duas frações são mais baixos que o anterior e de valores próximos entre si.

c) Nessas rochas metamórficas decompostas, os grãos de quartzo apresentam nas duas frações, grossa e fina, graus de arredondamento extremamente baixos e, em geral, na fração fina, os graus de arredondamento são maiores, em relaçāo à fração grossa.

Pode-se verificar que os arenitos de Poços de Caldas se enquadram melhor entre os do grupo b, isto é, entre os aquosos. Esste critério, entretanto, foi usado com cautela, pois arenitos como os de Poços de Caldas, provàvelmente de origem mista (como veremos adiante), devem ter sofrido influência das eruptivas alcalinas, que modificaram, em parte, o grau de arredondamento dos seus componentes.

Brilho: E' o brilho um importante meio para se distinguir grãos de areia trabalhados pelo vento daqueles trabalhados pela água. Fizemos algumas determinações do brilho usan- 
do a técnica de Cailleux (11, pp. 11-19) Segundo êste autor, devemos verificar o brilho em grãos bem arredondados. Nós fizemos observações não só nos grãos de areia arredondados, como também nos angulosos (fração granulométrica de 210105 microns) pelas seguintes razões:

1 - O nosso sedimento arenoso não mostrou grãos de areia bem arredondados em quantidade suficiente. Como já foi visto antes, nos resultados da determinação do grau de arredondamento, raras foram as médias superiores a 0,3 .

2 - O brilho fosco, em grãos bem arredondados, pode ser produzido por processo abrasivo, em virtude de tôda a superfície do grão de areia estar exposta. Quando, porém, existirem reentrâncias no grão de areia e essas reentrâncias apresentarem brilho fosco, é possivel que êsse brilho se deva mais ao ataque de soluções que ao processo abrasivo pròpriamente dito. $\mathrm{Na}$ da impede, nessas circunstâncias, que grãos bem arredondados tenham também superfície fosca provocada pelo ataque de soluções e não por razões de abrasão. Considerando essas limitações ao método, foi desnecessária uma contagem porcentual do número de grãos brilhantes e foscos de cada amostra, no nosso caso. Algumas determinações aproximadas deram os seguintes resultados: para as amostras do grupo 1, 2 e 4 a maioria dos grãos de areia foi do tipo brilhante. Os grãos de areia foscos dessas amostras mostraram-se corroidos. Para as amostras 6a e 10 foram encontradas quantidades aproximadamente iguais de foscos e brilhantes. Em tôdas as restantes amostras predominou o número de foscos em relação aos brilhantes. As amostras do grupo 7 mostraram maior quantidade de grãos bem arredondados foscos que tôdas as outras amostras. Pode-se dizer que, em conjunto as amostras de arenitos apresentaram maior quantidade de grãos foscos que brilhantes. Aquêles são do tipo corroido, preponderantemente.

Análise mineralógica: Do material retido em cada peneira da análise granulométrica, foram contados ao microscópio 100 grãos escolhidos ao acaso. Em seguida, foram calculadas as 
médias ponderais, de acôrdo com as proporções das porcentagens e, a partir destas, a composição mineralógica total. A tabela 3 mostra a composição porcentual aproximada dos diversos arenitos e siltes, excetuando-se os minerais pesados.

Minerais pesados: 20 gramas de cada amostra desagregada contendo tôdas as frações granulométricas foram atacadas por ácido clorídrico impuro, a quente. Em seguida, foram lavadas em água e sêcas em estufa. Depois disso, foram lançadas em bromofórmio a fim de serem separados os minerais pesados. Éstes correspondem, em geral, a menos que $1 \%$ aproximadamente do pêso de cada amostra. Tôdas as amostras apresentaram uma boa porcentagem de zircão (vide tabela 4) O mínimo observado foi de $30 \%$. em relaçño aos demais minerais pesados, na amostra $10 \mathrm{~b}$.

Em resumo, as amostras 7, 8, 9 e 10 possuem maior variabilidade de minerais pesados. Nestas amostras ocorre também Jeucoxênio em certa quantidade. Os minerais opacos não foram diagnosticados, por dificuldades técnicas na sua determinação.

Em tôdas as amostras, ocorre o mineral bauerita, ora na fraçāo leve, ora na fração pesada. Por causa dessa propriedade, não entrou no cômputo entre os minerais pesados pròpriamente ditos. A bauerita parece ser o resultado da lixiviação da biotita. E' isótropa ao microscópio. Em certos pontos dêste mineral, aparecem aglomerados microcristalinos de quartzo. Segundo Brammal e Harwood (9, pp. 20-26), a biotita submetida a condições especiais de alteração é capaz de dar bauerita e resíduo contendo titânio.

O anatásio apareceu sempre idiomorfo, freqüentemente formando agregados minerais, que servem algumas vêzes como cimento aos grãos de quartzo. Suas características indicam autigenia.

O zircāo, em geral bem arredondado; apresentou freqüentemente tons púrpura e alongamento médio de 0,2 milímetros; quando prismático, mostrou freqüentemente terminaçāo ‘m pirâmides altas. 
A turmalina foi encontrada sempre bem arredondada de côr castanha, parda, ou azulada, com inclusões raras.

O rutilo apresentou sempre forma prismática arredondada e côr laranja avermelhada a amarelada.

A monazita foi encontrada em quantidade na amostra 5a. Apresentou-se, no caso, com tamanho médio de 0,5 milímetros e bem arredondada.

A granada mostrou-se incolor na maioria das vêzes.

$\mathrm{O}$ corindon, azul característico apresentou-se às vêzes arredondado.

A hornblenda e a apatita foram determinadas precàriamente, por terem sido encontradas em fragmentos muito peguenos.

Estruturas sedimentares singenéticas e epigenéticas: Os sedimentos alcançam sua máxima espessura em Aguas da Prata e ao norte de Andradas, na fazenda Pinheirinho, a poucos cuilômetros desta cidade. Nesses locais, acamou em primeiro

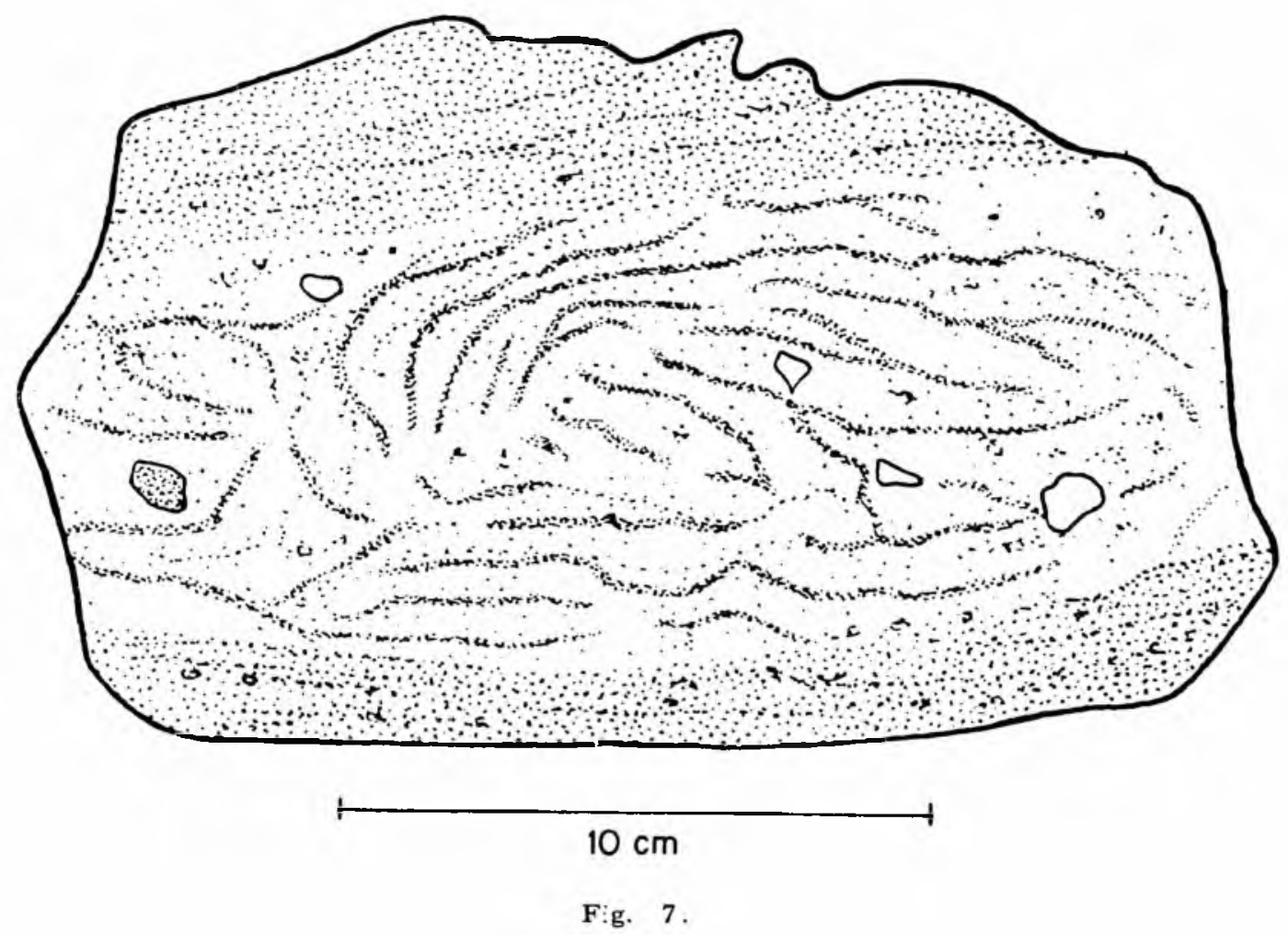

lugar material predominantemente siltoso e argiloso em conjunto, com espessura aproximada de 60 metros. Acima dessa 
camada mista, aparece arenito com aproximadamente 30 metros de espessura. Nos outros pontos do planalto, foram encontrados unicamente arenitos. Quando sobrepostos, parece não haver inconformidade entre o sedimento siltoso-argiloso e o arenoso. São freqüentes leitos finos e espessos de arenito intercalados no siltito e argilito. Ocorrem também, nesse sedimento, leitos de muscovita e bauerita, cujas plaquetas atingem, em casos raros, um centímetro de tamanho e leitos de seixos de gnais ou arenito de tamanho máximo de alguns centímetros $O$ material fino apresentou acamamento laminar paralelo $e$ rítmico e, quando inclinado, os ângulos de mergulho não são maiores que $20^{\circ} \mathrm{O}$ arenito apresenta estratificação plana paralela, ou cruzada, na grande maioria dos casos. A estratificação cruzada, no máximo, em ângulos de $30^{\circ} \mathrm{Na}$ Serra do $\mathrm{Mi}$ rante ocorre sedimento arcosiano imaturo em tipo de depósito torrencial, Lahee $(24$, p. 83 ), de cuja textura damos um esquema na figura 7 E' freqüente encontrar-se nos arenitos, que afloram na Serra do Mirante, brecha intraformacional de argilito ou arenito fino e concentrações limoníticas. Devem ser resultantes do dissecamento de material argiloso, que foi, posteriormente depositado com o outro sedimento. Na Serra do Quartel, a NE de Águas da Prata, existe pedreira de arenito silicificado, onde se encontram nódulos esferóides, assemelhando-se bastante aos do arenito Botucatu encontrados na estrada de rodagem, entre Analândia e Descalvado, nas encostas da Serra do Cuscuzeiro (Estado de São Paulo) São nódulos às vêzes ôcos, às vêzes contendo areia e argila friáveis, outras vêzes compactos até o centro. Apresentam sempre camadas concêntricas discerníveis ora por sua maior concentração de calcedônea, ora por maior concentração ferruginosa ou manganosa.

Não foram encontrados até o momento, sedimentos semelhantes aos estudados fora da área das intrusões alcalinas. Os mais próximos ocorrem em afloramentos descontínuos, na Ser$r s$ do Mirante. Apoiam-se sôbre o gnais. No seu ponto mais alto (1580 metros aproximadamente) êstes sedimentos parecem estar ligeiramente basculados para W. Provàvelmente, aí também ocorrem rochas alcalinas, pelo fato do talude da mesma 
serra, na altitude de 1500 metros, conter blocos de tinguaito, de mistura com os de arenito. Para o sul, descreve esta serra uma ligeira curvatura para $\mathrm{E}$, acompanhando externamente a Serra do Paiol, terminando em Aguas da Prata a 800 metros de altitude. $O$ arenito capeia estas elevações, cujas cristas passam gradualmente da cota 800 a 1580 metros. Em Águas da Prata e ao norte de Andradas, aparecem nestes sedimentos inúmeras perturbações estruturais (falhamentos, basculamentos etc.). Dificilmente são observados adernamentos de blocos em ângulo superior a 10' Nas outras ocorrências sāo constatadas inúmeı as intrusōes alcalinas nos arenitos da regiāo. Diques radiais, em relação ao centro do planalto são freqüentes nas pedreiras de arenito próximas à barragem do Rio das Antas até Poços de Caldas. Em vista aérea tem-se a clara impressão de que os afloramentos de arenito seguem uma linha interrompida ao longo da borda do planalto, acompanhando-a, como incrustação interna das encostas montanhosas do grande círculo. Freitas (3, p. 37) já havia feito observações semelhantes. A posição dos mesmos varia entre cota de 1000 metros até a cota de 1500 metros, mergulhando geralmente para o interior

Considerações sôbre os sedimentos arenosos. Certos arenitos por nós estudados, vide figura 7, além de apresentarem textura "turbilhonar" possuem certa quantidade de feldspato, microclina em geral, também constatada por Branco (10, p. 9), que por decomposição dá à rocha um aspecto salpicado. Êsse sedimento arcosiano apresenta acamamento do tipo torrencial, isto é, alternância de camadas horizontais paralelas com estratos cruzados ou caóticos, ou ainda alternância de camadas paralelas grossas e finas. Segundo vários autores, Twenhoffel (34, p. 313), Krynine (23, pp. 353-363), a presença de feldspato nos arenitos dêsse tipo indica decomposição e retirada sem completa destruiçāo dos minerais, erosão rápida, pouco transporte e soterramento em curto espaço de tempo. O tipo de acamamento irregular sugere, por outro lado, variações de competêncıa durante o processo de sedimentação. Outros dados, que apontam condições variadas de sedimentação, são as alternân- 
cias de arenito e siltito em Águas da Prata e ao norte de Ancradas. Éstes arenitos, intercalados no siltito, possuem notáveis semelhanças com os demais arenitos da mesma região (incluindo o arenito, que ocorre acima do siltito, em espêssa camada) Têm o mesmo grau de seleção, mediana granulométrica sempre na fração arenosa, estratificação em geral cruzada etc. Há casos excepcionais, como por exemplo nas proximidades da Cachoei . ra do Ozório, em que o arenito apresenta estratificação inclinada curta e curva, ou ainda, níveis de seixos e areia grosseira, indicando, possivelmente, locais onde agiram correntes aquosas. Normalmente o siltito mostra laminação, produzida possivelmente em condições calmas. Como já foi dito anteriormente, existem leitos de mica no siltito, cujos tragmentos, às vêzes, alcançam um centímetro de tamanho. Talvez seja êsse o indício c.e proximidade da fonte, ou condiçôes calmas de sedimentação, Krumbein e Sloss (16), pois com o transporte, a mica se frag: menta, diminuindo de tamanho. Como se pode depreender das curvas cumulativas, o siltito nem sempre se apresenta bem selecionado, talvez por defeito de amostragem.

Fonte dos sedimentos: Fazendo uso do cálculo proposicional segundo modêlo de Reichenbach (29, p. 99), podemos concluir:

1 - O sedimento estudado deve ter diversas procedências.

2 - Êste sedimento é difícil de ser encontrado, por ter-se sedimentado, provàvelmente, em diferentes condições de ambiente.

Estudando os minerais pesados, pudemos constatar serem êstes comuns de rochas ácidas. Assim, a zirconita e monazita têm sua origem em rochas igneas ácidas ou intermediárias, o mesmo podendo-se dizer do anatásio, que é geralmente autígeno por decomposição de ilmenita ou mineral titanífero, Milner (27, p. 235) A côr púrpcira da zirconita, no caso, é indício de idade arqueana, Saldanła e Frarıo (17, p. 48) Os minerais pesados: turmalina, rutilo, granada e córindon provêm de rochas metamórficas ou ígneas ácidas. Os 
seixos e fragmentos encontrados nos arenitos e siltitos de Águas da Prata são de gnais ou de arenito cimentado por limonita. Os minerais pesados do seixo de arenito apresentam 90\%, aproximadamente, de turmalina e pequena porcentagem de zirconita; de modo que, não houve confirmação da primeira hipót€:se na prática. Quanto à segunda, sabemos que, até agora, nāo é encontrado êsse mesmo tipo de sedimento em outras partes, a não ser dentro do planalto de Poços de Caldas ou junto a êle, na Serra do Mirante. Podemos admitir que, se todo o pacote sedimentar mostra alternância de rochas formadas em condições diferentes, então sua ocorrência deve estar limitada a uma linha de sobreposição de meios e ambientes diversos de sedimentação. Tal situação, por exemplo, poderia existir junto a montanhas no deserto. O siltiıo e argilito depositar-se-iam em lagoas. As intercalaçōes de arenito podem ser explicadas como transgressões passageiras de areias do deserto que, por fim, devem ter sobrepujado os depósitos de silte. Fato que apoia essa interpretaçāo é que êsse tipo de sedimento existe em "playas" atuais, Hamilton (21), apresentando espessuras semelhantes às por nós encontradas, o mesmo acontecendo em desertos do passado, Martin e Korn: (26, p. 88) Estudos de Barrel (5, p. 285294) mostram serem comuns em zonas áridas ou semi-áridas sedimentos dêsse tipo.

Idade dos arenitos: Até agora nenhum fóssil foi verificado nos sedimentos arenosos considerados. Nessas condições, não nos é possivel correlacionar, com segurança, o sedimento e nem datá-lo. Faremos uso então de caracteres litológicos, para podermos compará-lo a outros. Quem examinar pela primeira vez os arenitos do planalto de Poços de Caldas fica logo sugestionado pelo seu aspecto friável e pela angulosidade dos grãos que o compõem. Derby (16), o primeiro geólogo a encarar êsse assunto, acreditou inicialmente na possibilidade de se tratar de quartzito do embasamento cristalino. Logo abandonou essa idéia, atribuindo idade carbonífera ao sedimento, pelo fato de ter encontrado nele intercalações de folhelho argiloso. À primeira vista, parece realmente um quartzito. Entretanto, as análises de arredondamento, tabela 2 , parecem indicar nāo 
terem êles sofrido metamorfismo suficiente para se transformarem em tal rocha, cujos grãos teriam angulosidade muito maior A segunda idéia de Derby encontra melhor apôio nos resultados sedimentológicos. Voltando à tabela 2, pode-se notar que o grau de arredondamento dos arenitos de Poços de Caldas, é semelhante aos dos arenitos fluviais e flúvio-glaciais €m geral. A título de comparação, damos, a seguir, os coeficientes de seleção de três sedimentos, dois arenitos flúvio-glaciais e um loessito, cujos histogramas foram obtidos por Leinz (25, pp. 17-24) Por êsses dados verificamos que o arenito de Pitanga (Estado de São Paulo) e o loessito de Rio do Sul (San1a Catarina) são bem selecionados com coeficientes de seleção äo redor de 2 . O arenito fino do Rio do Sul, ao contrário, deu seleção medíocre e ao redor de 10 . Os dois primeiros, entretanto, mostram como o sedimento glacial retrabalhado pode apresentar-se bem selecionado, perfeitamente comparável aos de Poços de Caldas. Existe, no entanto, forte discrepância com relação aos minerais pesados. Enquanto os sedimentos glaciais ou flúvio-glaciais contêm de modo uniforme a granada, predominantemente, havendo também certa freqüência de turmalina e apatita, Leinz (25, pp. 27-28); nos nossos sedimentos, a granada e a apatita aparecem em porcentagem muito baixa. Fiste último dado afasta a hipótese de Derby de que os arenitos por êle encontrados, próximos e dentro do planalto de Poços de Caldas, sejam correlacionáveis aos sedimentos flúvio-glaciais.

Como vimos na introdução dêste trabalho, os autores mais modernos apontam semelhanças dos arenitos considerados, com o arenito Botucatu, principalmente devido ao conteúdo em feldspato quase sempre presente em sua composição Foram então comparados os nossos dados, aos obtidos por Carvalho (12) em estudos realizados sôbre o arenito Botucatu no Estado de São Paulo e também aos de outros autores. Pode-se dizer que, apesar de nossos arenitos apresentarem bom grau de seleção granulométrica, tabela 1, possuem êles maior quantidade de argila do que os arenitos estudados por Carvalho (12). Esta autora, comparando o arenito Botucatu a areias desérticas da Africa, verificou que há em ambos, de um modo geral: 
1 - Muito material bem selecionado para a granulação de 500 e 200 microns, chegando a representar $96 \%$ da amostra.

2 - Muito pouco material mais fino e mais grosso que a moda.

Os nossos histogramas, obtidos a partir das curvas cumulativas, mostram que a moda se situa no intervalo de 500 a 125 microns, em geral mais próxima a êste último valor e em porcentagem aproximadamente de $45 \mathrm{em}$ relaçāo ao total. Acima e abaixo da moda se distribui o restante material correspondente a $65 \%$ da amostra. Como se vê, não há perfeita correspondência entre os dados daquela autora e os nossos. Bagnold, (1, pp. 118-124) teve oportunidade de verificar que a estratificação dos sedimentos eólicos mostra haver mudanças rápidas nas condições de formação dêsses depósitos. Assim, as camadas são homogêneas só na espessura de poucos milímetros. Amostragem em maior espessura faz com que, junto à moda, apareça uma outra classe de granulação, que a acompanha em porcentagem. Ainda maiores discrepâncias na granulometria são obtidas, quando uma duna se move, havendo mistura de duas camadas, uma de areia grossa e uma de areia fina, formando depósito misto. Por essas ou outras razōes, não há correspondência granulométrica entre os arenitos por nós estudados e o arenito Botucatu. Quanto ao grau de arredondamento, os arenitos de Poços de Caldas apresentaram grãos em média pouco arredondados, como vimos anteriormente, não só nas frações finas, como nas grossas, tabela 2. Isto, segundo Twenhoffel (34, pp. 308-309) não é suficiente para que se elimine a hipótese do sedimento em questão ter sofrido transporte eólico. Diz aquêle autor que pequeno transporte, ou ainda a retomada do sedimento por outro agente, pode modificar o arredondamento original dos componentes. De qualquer forma, o arredondamento no caso não é do tipo eólico, enquadrando-se melhor entre os do tipo aquoso, tabela 2. Comparando os nossos sedimentos, de grau de arredondamento ao redor de 0,4 , no máximo, com os de Carvalho, no máximo ao redor de 0,7 , vê-se que os nossos são completamente diferentes daqueles. Quanto ao brilho, já vimos antes que 
o grão fosco só pode ser determinado quando bem arredondado, c que não é o caso. Dessa forma, não é possível estabelecer comparação com outros arenitos, quanto a êsse caráter, que pode também surgir em circunstâncias outras que em ambiente eólico. Os minerais pesados serviram de base mais segura para estabelecimento de semelhanças entre as duas formações. O arenito Botucatú descrito por Carvalho (12) apresenta, além dos minerais por nós encontrados, ainda: barita, epidoto e estaurolita, faltando a êle anatásio, comum nos de Poços de Caldas. Entretanto, podemos dizer que ambos divergem pouco, principalmente se considerarmos a grande distância do local onde foram obtidas as amostras estudadas por aquela autora (a W do Estado de São Paulo, quase nos limites com o Estado co Paraná) em relação aos de Pcços de Caldas. E' possível e mesmo provável que haja uma certa semelhança de alguns arenitos de Poços de Caldas com os da série Bauru, pois têm em comum o ambiente aquoso de sedimentação. E' interessante comparar alguns dados nossos com os de Freitas (20) sôbre a série Eauru. Já se nota flagrante diferença na composição dos dois arenitos. Para os da série Bauru, o teor de argila é muito maior, Freitas (20, pp. 80-81) do que nos nossos arenitos (figuras 2, $3.4,5$ e 6) Por outro lado, diz Freitas no seu trabalho, que os sedimentos por êle estudados apresentam grande variabilidade dos coeficientes de seleção, geralmente medíocres, o que não é o nosso caso, tabela 1 Os arenitos por nós estudados possuem, freqüentemente, teor mais alto em quartzo, superior ao máximo (85\%) dos sedimentos estudados por Freitas. Além disso, os grãos de areia dêstes últimos possuem tamanho máximo de 0,125 milímetros, ultrapassado pelo tamanho médio dos componentes dos arenitos de Poços de Caldas, com valores ao redor de 0,3 milímetros. Por outro lado, o teor em zirconita dos arenitos da série Bauru é sempre baixo, em contraste com os minerais pesados dos arenitos de Poços de Caldas. Aquêles são também comuns de rochas metamórficas e de rochas basálticas, contrastando com êstes, comuns de rochas ígneas áciclas. São ambos semelhantes, quanto ao grau de arredondamento, tabela 2, entretanto como já foi dito e como veremos adian- 
1e, o arenito de Poços de Caldas parece ter sofrido a influência do magma alcalino que parece ter-lhe modificado em parte 0 grau de arredondamento dos componentes. Além disso, em Águas da Prata e ao norte de Andradas, existe diabásio cortando os arenitos. Fica assim eliminada a hipótese de, pelo menos êstes, serem da série Bauru. Deixamos de comparar os siltitos que ocorrem abaixo da última intercalação de arenito com outras formaçōes sedimentares, porque sòmente as camadas superiores ocorrem em tôda a área estudada e intervieram nos processos vulcânicos. Considerando as analogias do arenito que ocorre na região de Poços de Caldas com as rochas da formação Botucatu, a correlação com tal arenito é aceita por nós, provisòriamente. $\mathrm{O}$ arenito Botucatu faz parte da série São Bento e acha-se em Águas da Prata cortado por diabásio da mesma série. Atribui-se-lhe idade supostamente triássica e sua situação estratigráfica não foi elucidada definitivamente. E' bem provável que êste arenito tenha se depositado, ou tenha sido remobilizado durante as manifestações alcalinas vulcânicas, pois aparece capeando lava ou tufo nas proximidades de Aguas da Prata, no leito e margens do Córrego do Quartel, Derby (16), e mais ao norte na fazenda Monte Alto intercalado com tufo. Foi impossível determinar o caráter da rocha alcalina decomposta e o tipo de contacto, por falta de melhores exposições. Em todo caso, o arenito está cortado e em contacto a quente com o tinguaito, na maioria dos outros afloramentos, fázendo-nos acreditar que êle se depositou antes das intrusões alcalinas e em ambiente misto eólico-aquoso. Se a situação dêsse material no tempo é problemática, por outro lado a sua situação espacial é de grande importância para estabelecer os fenômenos estruturais da região.

\section{BRECHAS}

Descrição: Entendemos por brecha, tendo por finalidade - mapeamento geolńgico, a rocha fragmentária ligada diretamente ao vulcanismo alcalino. Como se pode ver na figura 1 . as brechas aparecem freqüentemente acompanhando os aflo- 
ramentos de arenito em linha bordejante interna do círculo alcalino. Há exceções, quanto aos dois afloramentos, que ocorrem no centro sul do planalto. São descritos os quatro tipos seguintes:

1 - Brecha de côr castanho-arroxeada encontrada nas proximidades da reprêsa do Rio das Antas até Aguas da Prata, seguindo a estrada de rodagem, que liga aquela cidade a Poços de Caldas, e, ao norte de Andradas em pequeno afloramento na fazenda Pinheirinho. Os afloramentos aparecem descontinuos, como se pode ver na figura 1 e no anexo mapa geológico da região. No planalto, essa brecha se encontra geralmente decomposta e, então, só reconhecível pelo fato de os fragmentos que a compõem mostrarem côr clara, que sobressai na massa escura castanha da matriz. De Cascata a Águas da Prata, estas rochas estão mais frescas:

a - Matriz: O exame macroscópico revela a existência de uma matriz de côr tipicamente castanho-arroxeada, que, decomposta, parece-se muito com a terra roxa proveniente das rochas básicas. E' de granulação fina afanítica, só se podendo distinguir o quartzo que aparece em grãos detríticos arredondados. De Cascata para Aguas da Prata, há um aumento de quartzo detrítico na matriz. O exame microscópico mostra em primeiro lugar, o alto teor em calcita. Esta se encontra, às vêzes formando agrupamentos de cristais grandes de geminação encurvada. Na maioria das vêzes, entretanto, forma massa de microcristais, que compōe o cimento e ocupa, em substituição, os espaços deixados por minerais, tanto da matriz como dos fiagmentos. Tal é sua quantidade que, acreditamos, deva talvez entrar em porcentagem superior a 60 na matriz dessas rochas. Ao lado da calcita existe também grande quantidade de hematita. E' ela responsável pela coloração dessas rochas, aparecendo microcristalina, castanho-avermelhada e opaca. Além ciêsses minerais, existe sempre em menor quantidade leucoxênio em massa fina, intersticial. A hematita aparece, freqüentemente, formando uma rêde irregular, onde a calcita e os fragmentos estão incluídos. As massas de cristais finos de calcita, 
geralmente arredondados, não têm limites bem definidos. e não são maiores que alguns milímetros. No caso de apresentarem limites nítidos, com relação à hematita e demais minerais, são por nós considerados como fragmentos e não mais como matriz.

b - Fragmentos: os fragmentos são de dois tipos principais: os fragmentos de rochas e os fragmentos de minerais.

Os fragmentos de rocha, macroscòpicamente, são de dois tipos. Os fragmentos claros, esbranquiçados, de textura grosseira em geral e os fragmentos escuros, castanhos de textura geralmente fina, afanitica. Os primeiros são isentos de quartzo, podendo-se distinguir, mesmo macroscòpicamente, ripas de feldspato que alcançam, no máximo, alguns milímetros de comprimento e também pontos esverdeados, onde houve cloritização. Os fragmentos escuros são, Íreqüentemente, pouco nítidos, realçando-se mal na matriz, cuja côr é semelhante, também escura e castanha. Ambos os tipos são angulosos, alcançando aquêles, em geral, maior tamanho. O maior encontrado foi de pouco mais de uma dezena de centímetros. Entre os minerais, o único que se pôde determinar macroscòpicamente, como vimos, é o quartzo, que aparece em relação aos outros, em tamanho maior Êste, assim como grãos detríticos de feldspato, ao microscópio, ressaltam na massa. Sua quantidade aumenta de tal modo nas proximidades de Aguas da Prata que chegam a formar um arenito de composição igual a $80 \%$ em relação à matriz, que, no caso, fica reduzida a simples cimento. Além do feldspato e do quartzo, existem sempre pequenas porcentagens de grãos de apatita, ora prismáticos bem ideomorfos, ora fraturados, pequenos fragmentos de magnetita ou ilmenita. A proporção máxima de quartzo obtida em relação ao feldspato foi de $90 \%$. Esste último se identifica em dois tipos: ortoclásio e albita, quase em iguais proporções, havendo, em certos casos, predominância do primeiro. Os fragmentos claros, ao microscópio se revelam como sendo principalmente de rocha, cuja textura e composição se assemelham ao diabásio. Apresentam ripas finas de plagioclásio, cujo tamanho máximo observado foi 3,5 milímetros de comprimento, para 0.3 milímetros de lar- 
gura, dispostos irregularmente. O espaço entre as ripas é ocupado por calcita e agregados alongados de magnetita ou ilmenita. Èsses fragmentos estão bastante decompostos; porém, foi possivel diagnosticar o feldspato como sendo albita com índice menor que o bálsamo e ângulo de extinção para os geminados, segundo a lei da albita ao redor de 14' Ao norte de Andradas, aparece essa mesma brecha com fragmentos grandes de gnais. Os fragmentos escuros são concentrações maiores de hematita ou fragmentos de arenito fino com maior quantidade de cimen1.c hematítico. Além dêsses fragmentos maiores, existem também alguns de aglomerados de calcita, ou quartzo, ou, ainda, feldspatos microgranulares, de extinção ondulante. Os grãos de quartzo acham-se freqüentemente atacados, apresentando cavidades de corrosão, ocupadas pela calcita. A brecha é composta aproximadamente por $60 \%$ de fragmentos e $40 \%$ de matriz. Os fragmentos estão desorientados; entretanto, nota-se acamamento dessa brecha na Serra do Paiol.

2 - Brecha de côr verde-azulada clara, encontrada nas proximidades do leito do Rio das Antas entre a Barragem e Poços de Caldas e também, isoladamente, na Vila de Cascata. Quando semi-decomposta, essa brecha apresenta côr azul clara ou cór castanha clara, confundindo-se com a primeira já descrita.

a - Matriz: - o exame macroscópico da rocha fresca mostra matriz afanítica manchada de azul e verde de modo irregular As manchas apresentam limite indefinido. Distinguemse na matriz fragmentos e grãos de quartzo. Aquêles ocorrem ๔m pequena quantidade representando, aproximadamente, $10 \%$ dia composição total. Ao microscópio, pode-se notar como componente da matriz o piroxênio alcalino, em prismas curtos ou $e m$ finas agulhas radiais, sempre ideomorfos e, ainda, calcita. Esta última, forma massa fina de microcristais ou agregados maiores sem limites nítidos com os demais componentes da matriz, como acontece na brecha 1, já descrita. Na brecha encontiada na Vila de Cascata, além dêsses componentes normais a egirina parece estar alterada em mineral fibroso de côr azulaaa clara. Em alguns pontos da rocha, falta a egirina totalmen- 
t€, ficando a matriz representada só por calcita. Leucoxênio aparece intersticial.

b - Fragmentos: Macroscòpicamente, distinguem-se fragmentos de rocha e de minerais. Foi possível, por exemplo, reconhecer fragmentos de gnais além de fragmentos de lava e arenito. Entretanto, só ao microscópio foi possivel diagnosticar melhor os diversos tipos. Pode-se dizer de início, que êstes são mais variados que os encontrados na brecha 1 Entretanto, cono naquela, muitos são os pedaços de rocha de textura diabásica com plagioclásios ripiformes de albita contendo magnetita intersticial. Existem também fragmentos de fonolito ou tinguaito cujos componentes são: feldspato, egirina e nefelina, microgranulares.

O arenito e o gnaiss não foram estudados ao microscópio. Além dêsses fragmentos, ocorrem conjuntos de agregados de feldspato ou quartzo, que ressaltam na matriz pelo seu tamanho. Os minerais detríticos mais comuns nessa brecha são êstes dois últimos, em proporções variáveis quanto aos níveis de uma sondagem, feita no sítio Bortolan, próximo à Barragem, junto à estrada de rodagem Poços de Caldas a Aguas da Prata. Amostras coletadas a 53 metros e 71 metros de profundidade continham como material detrítico ùnicamente, feldspato. Na superfície, algumas amostras contêm muito quartzo detrítico e raros grãos de feldspato. Êste último é geralmente do tipo plagioclásio e em quantidade menor ortoclásio e microclínio. Tanto o feldspato como o quartzo acham-se muitas vêzes corroídos e substituídos pela calcita. Além dêsses minerais aparece a biotita em certos casos e apatita. A biotita pode ocorrer em grandes cristais, alguns de 0,5 centímetros de comprimento. A apatita é comum em cristais ideomorfos. De todos os fragmentos observados, o maior não ultrapassou o tamanho de 10 centímetros, sempre encontrados dispostos desorientadamente. Em Cascata e nas proximidades da lionte sôbre o Rio das Antas, a brecha está acamada.

3 - Brecha associada diretamente às rochas ígneas alcalinas, encontrada ao norte de Poços de Caldas, na estrada que 
liga esta cidade à Pedra Balão e na Serra do Paiol nas elevações que limitam o planalto a SW Estas brechas são representadas, na figura 1, por triângulos. Quem sai de Poços de Caldas em visita à Pedra Balão encontra na subida da Serra, que separa êsses dois pontos, um tinguaito comum de côr negra e textura afanítica, que passa gradualmente a uma rocha de mesmo aspecto, contendo fragmentos de vários tipos. A SW do planalto, capeando as elevações maiores e as colinas que o limitam, é encontrado um tinguaito que, quando fresco, é de côr negra como o anterior, passando, às vêzes, a um tipo de granulação mais grosseira, assemelhando-se macroscòpicamente a um microfoiaito. Apresenta, em pontos dispersos de sua massa, fragmentos de rocha de textura mais fina. Os fragmentos podem estar, às vêzes, distanciados de metros, outras vêzes distantes de alguns milímetros, formando um agrupamento denso.

a - Matriz: A matriz, do ponto de vista macroscópico, é a mesma em ambos os casos. Diverge esta última daquela quanto à textura, mais grosseira. Ambas possuem grande semelhança na composição. Ao microscópio, a matriz tem aspecto de tinguaito. A primeira, de Poços de Caldas, é porém mais rica em nefelina, que se apresenta ideomorfa em cristais grandes, até dois milímetros de comprimento. Os feldspatos presentes são sanidina e ortoclásio de 1,5 milímetros, no máximo $\mathrm{Na}$ brecha de Poços de Caldas, o feldspato e a nefelina estão freqüentemente alterados. O feltro da matriz è, em ambas, constituído de cristais menores, cujo tamanho é de 0,15 milímetros, no máximo. E' composta dos seguintes minerais: piroxênio sódico. nefelina e feldspato.

b - Fragmentos: Distinguem-se quatro tipos de fragmentos, macroscòpicamente, na brecha de Poços de Caldas. São êles os seguintes: rocha esverdeada muito escura, cujos minerais prismáticos faneríticos são, no máximo de um centímetro; rocha clara de cristais feldspáticos faneríticos com alguns fêmicos acessórios; rocha fina afanítica de côr preta; arenito. A primeira, ao microscópio, mostrou ser uma rocha piroxênica, às vêzes poiquilitica, englobando biotita (que também é muito 
freqüente na rocha) feldspato e apatita. Os acessórios são: titanita, apatita e magnetita. Augita ocorre, passando, nas beiradas, a piroxênio sódico. Ao microscópio, a segunda se mostra bastante decomposta; é do tipo foiaito com grandes cristais de ortoclásio e nefelina. O piroxênio sódico é prismático e intersticial. Aparece biotita no contacto do fragmento e matriz. A patita é acessório comum dessas rochas, na forma de agulhas. O terceiro tipo de fragmentos mostrou ser, ao microscópio, uma rocha microcristalina formada essencialmente de feldspato, nefelina e piroxênio sódico. No centro, passa a ter uma textura esferulítica. O arenito foi observado macroscòpicamente. Além dêsses dois tipos, aparece na Fonte Paiol, a três quilômetros de Aguas da Prata, na estrada de rodagem para Cascata, a 900 metros de altitude, uma brecha de lava de côr parda esverdeada ou roxa escura, fragmentária, lítica, bastante decomposta. A matriz é pulverulenta, rica em hematita, magnetita (?), calcita, apatita, clorita e, às vêzes, biotita, onde se destacam fragnientos de lava básica alcalina, com cristais de augita e analcita, porfíricos, de 1,5 centímetros de tamanho máximo. Outros fragmentos são de rocha formada exclusivamente de piroxênio, magnetita ou limenita, de textura panidiomorfa ou panipidiomorfa, cujos interstícios são preenchidos por calcita. Como acessório, ocorre a titanita, perovskita (?) e granada (?) Os fragmentos menores são de aglomerados de feldspato em decomposição, possivelmente analcita, clorita, olivina (?) reconhecível só pela forma e apatita. Em sondagem de 100 metros de profundidade, essa rocha se apresentou contínua, contendo blocos com tamanho máximo de algumas dezenas de centímetros, dispostos desorientadamente. A sondagem não atingiu o fim da ocorrência em profundidade.

4 - Brecha piroclástica ou tufo, encontrada na estrada de ferro ligando Águas da Prata e Cascata, a 500 metros, aproximadamente, acima do cruzamento daquela, com a estrada de rodagem para a "Fonte Platina" E' rocha fina, afanítica, estratificada, de côr parda, contendo em certos níveis bombas e blocos acamados. Ao microscópio, mostra matriz de poeira vul. 
cânica castanha escura a pardacenta, decomposta, contendo fragmentos maiores de vidro e lava microcristalina, geralmente angulosos, de côr parda clara, outras vêzes, arredondados. Êstes são, às vêzes, de material criptocristalino. Material semelhante a êste (e que parece ser também tufáceo) ocorre no centro sul do planalto, nos dois afloramentos centrais, marcados na figura 1 e também no mapa anexo, na estrada de rodagem que liga Poços de Caldas a Andradas, junto à fazenda Carlito Junqueira. A melhor exposição é de 50 metros de comprimento, aproximadamente. E' rocha acamada em leitos rítmicos, cuja espessura é de 1 a 2 centímetros no máximo, muito decomposta e de côr roxa e cinza, contendo quartzo rolado Acha-se atravessada por um dique de rocha, provàvelmente alcalina, também decomposta.

Considerações gerais sôbre as brechas. Na maioria dos sedimentos, material de origem vulcânica está presente só em traços, sem importância para constituição da rocha. Entretanto, por ser material muito fino e originário do magma decompõe-se fàcilmente nas condições reinantes na superfície, tornando-se difícil de reconhecer em sedimentos arenosos ou argilosos antigos. Em regiões de ativo vulcanismo, os sedimentos podem conter, exclusivamente, produtos de ejecção a. por conseguinte, são chamados de depósitos piroclásticos. E' material formado principalmente por explosões violentas, em que lava e rocha sólida são pulverizadas e lançadas ao ar Cainco na superfície da terra, comporta-se como qualquer outro tipo de sedimento, podendo ser retransportado tanto por vento cono por água e misturado a fragmentos detríticos de outras procedências. Tratando-se de material completamente desagregado e sôlto, é fàcilmente erodido. Êsses depósitos sub-aéreos dificilmente são preservados da destruiçāo por erosão. Por cutro lado, a decomposição química nesses depósitos se realiza crm facilidade, pela circunstância do estado subdivicido e arranjo frouxo de seus componentes. Além dêsses tipos de brechas vulcânicas, há as formadas por fraturamento durante explosões, sem ejecção. São êstes formados por aflouxamento e fratura- 
mento do "teto" e da "rôlha" vulcânicos por fôrças da pressão dos gases acumulados que procuram saída, Cloos (13). Há nesses casos, um ajustamento de fendas do edifício vulcânico. O material original, fraturado pelas pressões, pode ser de diversos tipos, tanto da rocha ígnea consolidada como também de matéria piroclástica depositada em erupções prévias.

Ésses tipos de brechas parecem estar representados na região de Poços de Caldas. A brecha, provàvelmente piroclástica de modo exclusivo, é aquela tipo 4, em que parece não ter havido contaminação por outro material que não o vulcânico. Nela não foi encontrado nenhum grão de areia arredondado. Os tipos 1 e 2 se enquadrariam, talvez, entre as brechas fraturadás por explosão, permeadas por gases. A favor dessa hipótese estāo os fatos:

1 - De que essas rochas se encontram acamadas em certas exposições, indicando sua origem sedimentar primária.

2 - De essas rochas conterem quartzo ou feldspato arredondados dispostos em maior ou menor concentração, em diversos níveis, indicando mais uma vez a origem detrítica de alguns de seus constituintes e seu arranjo original sedimentar.

3 - De terem sofrido modificações na composição da rocha, posteriormente à sedimentação. Pode-se citar a transformação sofrida pelos plagioclásios, que, provindo de uma rocha possivelmente do tipo do diabásio, foram alterados em albita perdendo seu conteúdo em cálcio.

4 - O caráter híbrido das brechas, que, como vimos na descrição, apresentam ao lado dos grãos de quartzo e feldspato detríticos também egirina ideomorfa, às vêzes formando amídalas. E' improvável que êste mineral seja detrítico, o mesmo podendo-se dizer da apatita, que ocorre como aquêle, às vêzes, em finas agulhas idiomorfas.

O terceiro tipo de brecha no planalto de Poços de Caldas, que não possui as qualidades dos sedimentos pròpriamente ditos, é a rocha fragmentária de matriz tinguaítica, tipo 3 já descrita, que se classifica entre as brechas magmáticas. Como foi 
visto antes, há dois tipos dessas brechas, um de xenólitos diversos e outro de fragmentos da mesma composição que a matriz de textura mais fina. O primeiro dêles estaria localizado numa fenda, por onde caminharia o magma, atravessando níveis litológicos diferentes, de onde teria arrancado fragmentos, trazendo-os à superfície, onde aflora. O segundo, por outro lado, é de pequena espessura. Parece que foram formados êstes últimos por uma quebra de rocha ígnea resfriada, posteriormente retomada e englobada por novo afluxo de magma. Há casos em que esta brecha forma superfícies ou tabuleiros, distinguíveis na topografia, com facilidade.

Idade das brechas. $O$ estudo das diversas brechas mostrou que os tipos 1, 2 e 3 possuem fragmentos de arenito. Evidentemente, é um indício de que essas brechas são posteriores à formação do sedimento arenoso. Entretanto, na estrada de rodagem entre Cascata e Águas da Prata, na altura da Fonte Deliciosa e, também, nas proximidades da Fazenda Monte Alto, ao norte de Aguas da Prata, existe de mistura com os detritos arenosos muita argila fina de côr cinza azulada salpicada de pontos claros e finamente estratificada. Seria êsse material resultado da deposição conjunta de arenito e tufo? O exame feito com auxílio da lupa revela semelhança desta rocha com áquela piroclástica descrita como tipo 4 das brechas. Entretanto, está mais intemperizada que o tufo pròpriamente dito e contém grande quantidade de quartzo detrítico, inexistente ráa outra rocha. E' provável, portanto, que tenha havido deposição simultânea dos arenitos e dos tufos nas fases iniciais do vulcanismo, ou que ambos tenham sido retrabalhados em época pos.terior Devido ao estado de decomposição da rocha arenosa, contendo possivelmente tufo, foi impossível determinar os seus componentes finos. Dêsse modo, fica o problema sem solução, podendo-se acreditar ser impossível a ocorrência de numerosas e boas exposições de tufo, pelo fato de êsse material resistir pouco ao intemperismo e erosão, como já vimos.

T'alvez se possa explicar a presença do arenito e siltito, tınto no planalto como na sua vizinhança, imaginando terem êles 
sido capeados por material piroclástico e lava que os protegeu, possibilitando a sua exumação em épocas modernas. Os arenitos mais afastados da região vulcânica não teriam tido a mesma sorte, sofrendo destruição erosiva já em épocas remotas. De qualquer forma, as brechas parecem ser posteriores ao arenito $\epsilon$ anteriores ao final das últimas manifestações vulcânicas, pois estão cortadas por intrusões alcalinas (tinguaito) em muitos pontos onde afloram. Além disso, possuem, em quantidade, fragmentos de diabásio, intrusivo sob a forma de diques ou sills nos arenitos de Aguas da Prata. Ésse detalhe revela serem estas krechas também posteriores às eruptivas básicas, fato êsse já citado por Freitas (19, p. 8)

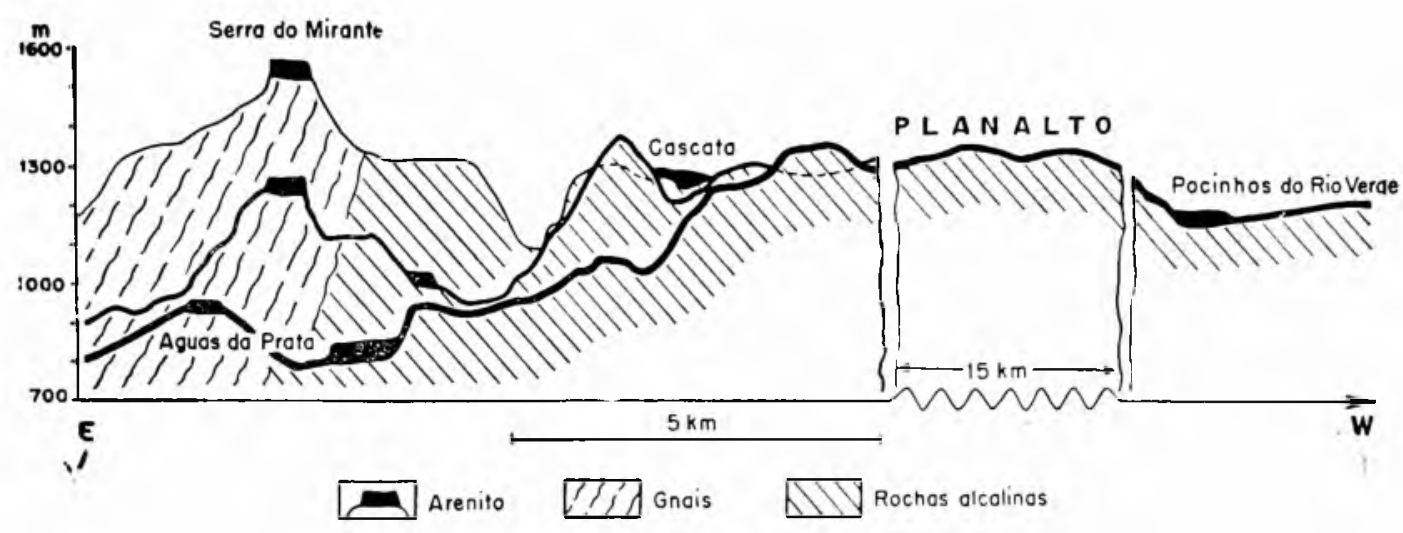

Fig. 8 .

As rochas clásticas no espaço. A fiģura 8 mostra três perfis, que cortam o planalto de Poços de Caldas na direçāo este-oeste. A distância entre êles é de 3.5 quilômetros, aproximadamente, começando de Águas da Prata para o norte. Os períis mostram as diversas posições que cs atloramentos de arenito tomam nessa regiāo. Evidentementc, pelas considerações já feitas, êsse arenito deveria encontrar-se em niveis equivalentes aos das demais rochas sedimentares da bacia do Paraná. Entretanto, ocupa na Serra do Mirante, o nivel de 1580 metros de altitude, aproximadamente. O mesmo fenomeno ocorre dentro do planalto, em que os areriitos acham-se deslocados de 400 metros para cima, em relação aos de Águas da Prata (a 820 metros de altitude) Além 
disso, como já vimos na figura1, o centro do planalto está livre de sedimentos arenosos e, na borda interna, êstes se encontram juntos e sôbre o tinguaito, nas mesmas cotas altimétricas (ao redor de $1.300 \mathrm{~m}$. de altitude) Houve, portanto com tôda a probabilidade, levantamento dos arenitos. Poderse-ia pensar que êstes tivessem ocupado as rampas das elevações do sopé ao cume dando a falsa impressão de levantamento. Entretanto, existe uma separação montanhosa entre os arenitos de dentro e de fora do planalto. Além disso, essas rochas do interior do planalto em geral mergulham para dentro do mesmo, mostrando mais uma vez terem se dissociado estruturalmente, com relação aos de fora.

Os arenitos do planalto parecem estar apoiados diretamente sôbre a rocha alcalina. Essa afirmação se baseia em um afloramento que ocorre nos arredores da cidade de Poços de Caldas, तW da mesma, na Serra de Poços. Nesse local, o arenito achas€ apoiado sôbre o tinguaito, mergulhando para o sul, aproximadamente de $30^{\circ} \mathrm{em}$ afloramento, que sobe quase até o cume dessas elevações. Lembremos também que o tufo já descrito, decomposto, que ocorre no centro sul do planalto, ocupa as mesmas cotas que o arenito da borda, isto é, aproximadamente 1.300 metros de altitude. Como veremos adiante, êsse é um dado muito importante para esclarecer as disposiçc̃es estruturais da região. Como já vimos, a brecha acompanha internamente a beirada montanhosa alcalina. É interessante notar a sєmelhança entre as brechas 1 e 2 . Apesar de se exibirem nos afloramentos com diferentes côres, isso provàvelmente se deve a circunstâncias secundárias de decomposição e intemperismo. Fato interessante, que demostra a sua semelhança, é o de conterem, como fragmentos, grande quantidade de diabásio e, muitas vêzes, arenito detrítico. Formam uma faixa contínua desde Poços de Caldas até Águas da Prata em linha semicircular Acreditamos que essas brechas tenham tido sua composição determinada pela litologia subjacente. Assim, em Águas da Prata, onde ocorre muito arenito e diabásio, a brecha é rica dêsse material e dos produtos de decomposição e alteração do 
diabásio, como vimos. Perto de Poços de Caldas, onde provàvelmente a influência alcalina se torna maior, a matriz dessa rocha muda, passando a conter enorme quantidade de piroxênio sódico. Infelizmente são poucos os dados que possuimos sôbre a espessura vertical dêsse tipo de rocha. Adiante voltaremos ao assunto.

Até agora foram descritos e interpretados fenômenos observados. Para chegarmos a uma interpretação plausível geral, muitas inferências terão que ser feitas sem termos para elas confirmação. Essas versões serão, portanto, do tipo conjectural. No entanto, será feita uma tentativa para deduzir dos fenômenos observados em superfície aquêles que ocorreram nas profundezas inacessíveis, ou, ainda aquêles cuja verificação direta é impossível. Observando o mapa geológico, o que primeiro chama a atenção é a disposição dos arenitos e brechas. O restante do planalto, a grande área central, apresenta aspecto homogêneo e pouca variabilidade litológica. Qual seria a razão para as rochas clásticas ocuparem a estreita faixa ao longo da cadeia montanhosa, que limita o planalto?

Origem das brechas. A origem sedimentar das brechas 1 e 2 pode ser verificada em alguns afloramentos pelo acamamento, apesar delas nem sempre apresentarem quartzo ou feldspato detríticos. Tal se dá desde Cascata, até as proximidades de Poços de Caldas.

Como vimos, existe grande semelhança litológica em tôda a extensa faixa em que ocorre esta rocha, de maneira que é plausivel considerar a maior ou menor concentração de grãos arredondados de quartzo ou feldspato, como uma variação simplesmente local.

Caracteres sedimentares das brechas:

1 - Acamamento em certos pontos, como visto acima.

2 - A presença freqüente de grãos detríticos de quartzo e feldspato na sua composição, que devem provir dos sedimentos arenosos da superfície.

Caracteres vulcânicos e magmáticos das brechas: 
1 - Blocos de arenito silicificado e recristalizado e blocos de gnais, que tomam parte como fragmentos maiores da brecha, possivelmente arrancados de pontos profundos, trazidos à superfície e atirados junto com os demais ejectólitos.

2 -- Os cristais idiomorfos de piroxênio sódico com texturas ígneas amigdaloides e os cristais idiomorfos de apatita.

3 - Movimentação e fraturamento, talvez causado por explosões e acomodações vulcânicas indicadas por:

a - Calcita, apresentando pìanos de geminação encurvados.

b - Grãos fraturados de quartzo.

Explicação: Com tôda probabilidade, essas rochas devem ter sofrido a percolação de gases, pois êstes podem encontrar caminho aberto no tufo, arenito e material piroclástico poroso, afrouxado em conseqüência dos abalos vulcânicos. Os gases alcançando a superfície, sofrem freqüentemente reação de oxidação com o ar atmosférico, Barth (6, p. 153), havendo, em conseqüência, grande aumento de temperatura.

Bciven (8, p. 84) afirma que, durante o processo de cristalização do magma alcalino, há um enriquecimento de voláteis, tais como: $\mathrm{H}_{2} \mathrm{O}, \mathrm{CO}_{2}, \mathrm{~S}, \mathrm{Cl}$ etc.. Tal é o aumento de voláteis, no magma alcalino, que êle é incluído por alguns autores, Turner e Verhoogen (33, p. 308) entre os pegmatitos. Dessa maneila seria fácil para êsses compostos, quer na forma de gases. cuer na forma de soluções, atacar e corroer os grãos de quartzo de certas rochas e, ao mesmo tempo, enriquecê-las de outros minerais. Explicar-se-ia, assim, o pequeno grau de arreciondamento nos grãos de quartzo dos arenitos, principalmente c: do planalto, diretamente envolvidos nos fenêmenos vulcânicos. Por outro lado, certos minerais, tais como o zircão, nacia sofreram, proàvelmente devido à grande estabilidade dêste mineral.

É possível que as considerações feitas acima possam explicar os processos metassomáticos que permitiram a formação 
de alguns minerais epigenéticos nas brechas e nos arenitos, tais como: anatásio idiomorfo, albita nos plagioclásios componentes dos fragmentos de diabásio etc..

De qualquer forma, existe ao longo dos afloramentos da brecha uma zona de fraqueza evidenciada pelos seguintes fatos:

Homogeneidade da litologia central do planalto, vide mapa geológico anexo.

Ocorrência de fontes quentes em Poços de Caldas e outros tipos em Pocinhos do Rio Verde, Águas da Prata e suas vizinhanças, nas regiões que circundam o planalto.

Ocorrência de calcita em grande quantidade na brecha, muneral inexistente nas rochas vizinhas alcalinas e talvez proveniente de profundidade, Sharid (31, p. 150)

Com êsses dados apontados acima, surgem dificuldades de ordem estrutural. Por exemplo, pode surgir a seguinte perguntá: até que profundidade se encontraria a faixa brechosa? Já vimos que, por sondagem, se apresenta contínua, até aproximadamente 100 metros de profundidade. Existem algumas boas exposições, ao longo do vale do Quartel, entre Cascata e Aguas ca Prata, em que se vê contato vertical entre brecha e rocha ígnea alcalina. Êsses afloramentos, litològicamente semelhantes, seguem com pequenas interrupções da cota, de 1.200 metros dé altitude a 820 metros de altitude. Deve-se entäo pensar em uma faixa de brecha de 400 metros de profundidade ou deve-se pensar em uma camada que se depositou em pequena espessura. descendo o planalto até a soleira das montanhas, em um vale pré-formado? Por enquanto, é impossivel dar uma resposta c. êsse problema.

Como vimos antes, é fato bem conhecido que os vulcões condicionam a subida do magma até a superfície, aparecendo rios pontos fracos da crosta. De fato, só onde existem fendas que permitam a passagem de matéria ígnea para o exterior é que se formam os edifícios vulcânicos. Assim, até mesmo nas zonas estáveis da crosta, os vulcões seguem alinhamentos estruturais, Hans Cloos (14), Umbgrove (35, pp. 296-297) obedecendo a condições tectônicas de falhas e fissuras. É interes- 
sante notar que essas rochas vulcânicas de continentes são, em Eeral, do tipo basáltico e seus diferenciados. Rochas leucíticas podem aparecer nesses casos; entretanto seu caráter alcalino parece ser causado por circunstâncias locais, Sitter (32, p. 373374) Cloos (13) verificou, em vários villões da Suabia que o próprio "neck" consolidado dos vulcões pode tomar o aspecto de brecha, quando quebrado e afrouxado durante o escape da pressão interna. Verificou êle a existência de dois tipos extremos de brecha, a dos blocos arredondados, com movimentação, expulsão de material e injeção de gases concomi-

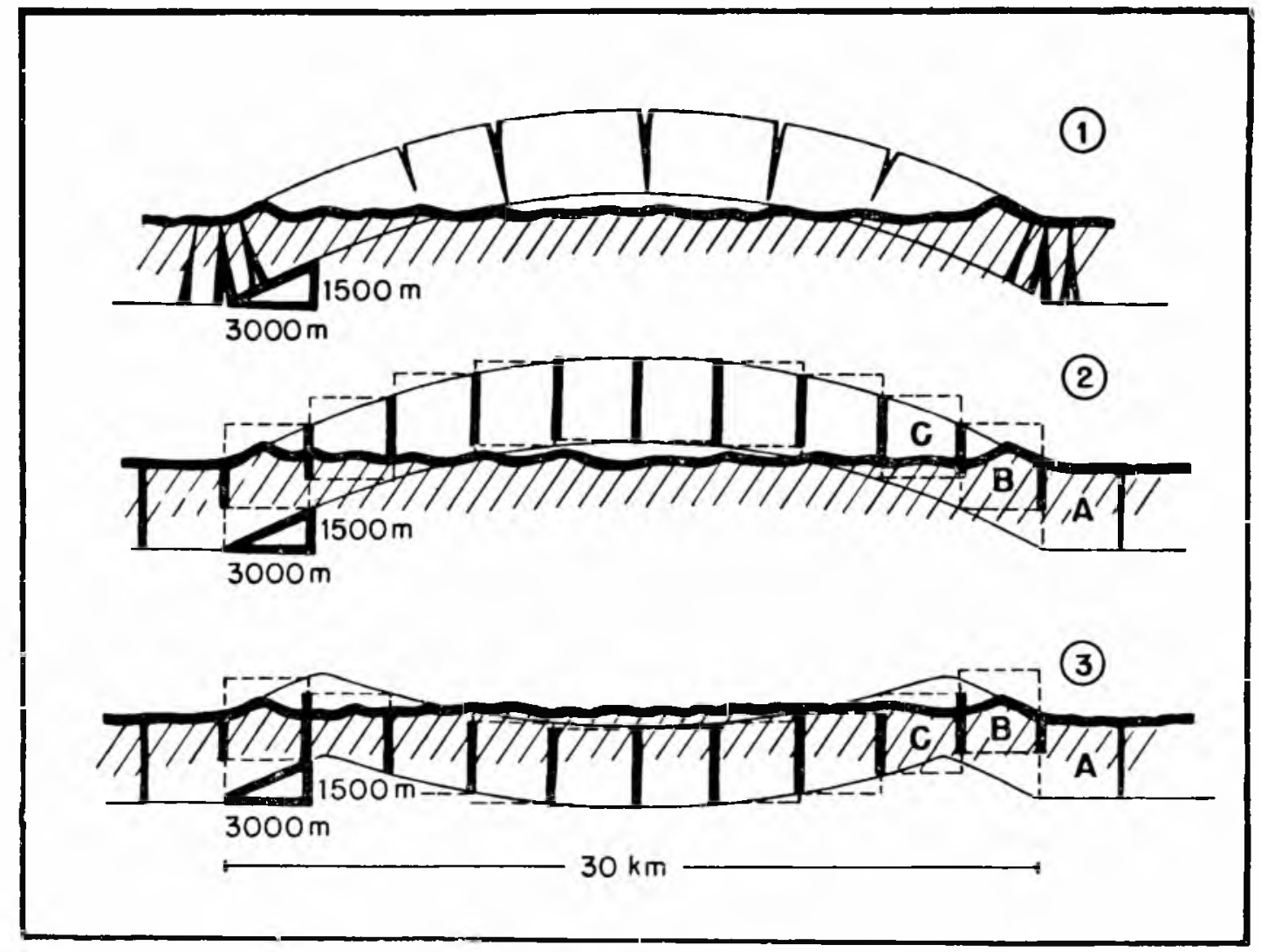

F.g. 9

tantemente, e segundo grupo mais simples, de fragmentos angulosos. Neste último caso, os blocos seriam fraturados devido à explosão, ou simplesmente expulsos por fenda, sem atrito suficiente para perderem os ângulos. Os nossos dados permitiram enquadrar os blocos tanto em um tipo como em outro; porém, tal é a complexidade dessas rochas e tal é a falta de bo- 
as exposições que acreditamos ser difícil, talvez impossível, situar na região estudada, os vulcões do passado.

As grandes estruturas. A altitude dos arenitos em Águas cia Prata e adjacências, em relação aos do planalto, figura 8; 0 mergulho acentuado, muitas vêzes vertical, das texturas fluidais nas rochas alcalinas da beirada; a marcante saliência desta última; o contacto quase vertical do gnais e rocha alcalina, parecem indicar ter havido avanço da intrusão para o alto, durante o seu "mise en place" Tanto os picos marginais do planalto, como o deslocamento dos arenitos com relação ao exterior do planalto, mostram haver uma declividade da ordem de 500 metros em um quilómetro, tomando como relação o sopé externo. Admitindo que a intrusão tivesse causado um abaulamento, em tal ângulo, relativo à horizontal, construimos, em escala reduzida, três perfís do planalto, para se iazerem especulações sôbre as condições estruturais em que teriam se originado e situado as brechas, figura 9. Experiências de Cloos e Ridel citados por Balk (2, p. 101) mostram que massa em movimento ao longo de obstrução estacionária, inúmeras fendas surgem no contacto da parte móvel e estável. Essas serão perpendiculares às linhas de máxima distensão local. Essa direção é facilmente determinada, pois é perpendicular às linhas fluidais da intrusão. Se o material usado para a experiência fôr relativamente fluido, as fendas estarão ao longo da faixa fina, no ponto onde a borda estacionária forma uma flexão brusca, figura 10. Entretanto, quanto menos fluido fôr o material, mais suave a flexão e mais larga será a zona de fratura, figura $10 \mathrm{C}$. O mesmo acontece à encaixante solidária à intrusiva, nas proximidades do contacto entre ambas. Das figuras 9 e 10 . pode-se chegar à seguinte conclusão: é no alto e nas bordas dessa estrutura que se desenvolvem melhor as fôrças de tensão. Formar-se-iam, assim, nesses locais, fendas por onde entraria n magma com mais facilidade. No segundo exemplo da figura 9 , há abaulamento externo, com translação de blocos falhados, sem adernamento, enquadrando-se no caso $\mathrm{C}$ de Balk. O mesmo se dá no terceiro esquema da figura 9, em que foi representado um suposto levantamento e abatimento Nesse esque- 
@na, entre os blocos A, B e C e seus simétricos, não só houve maior movimentação, como também as superfícies de contacto, representadas por linhas grossas verticais são mais curtas, relativamente aos outros blocos do conjunto. Sob o ponto de vista

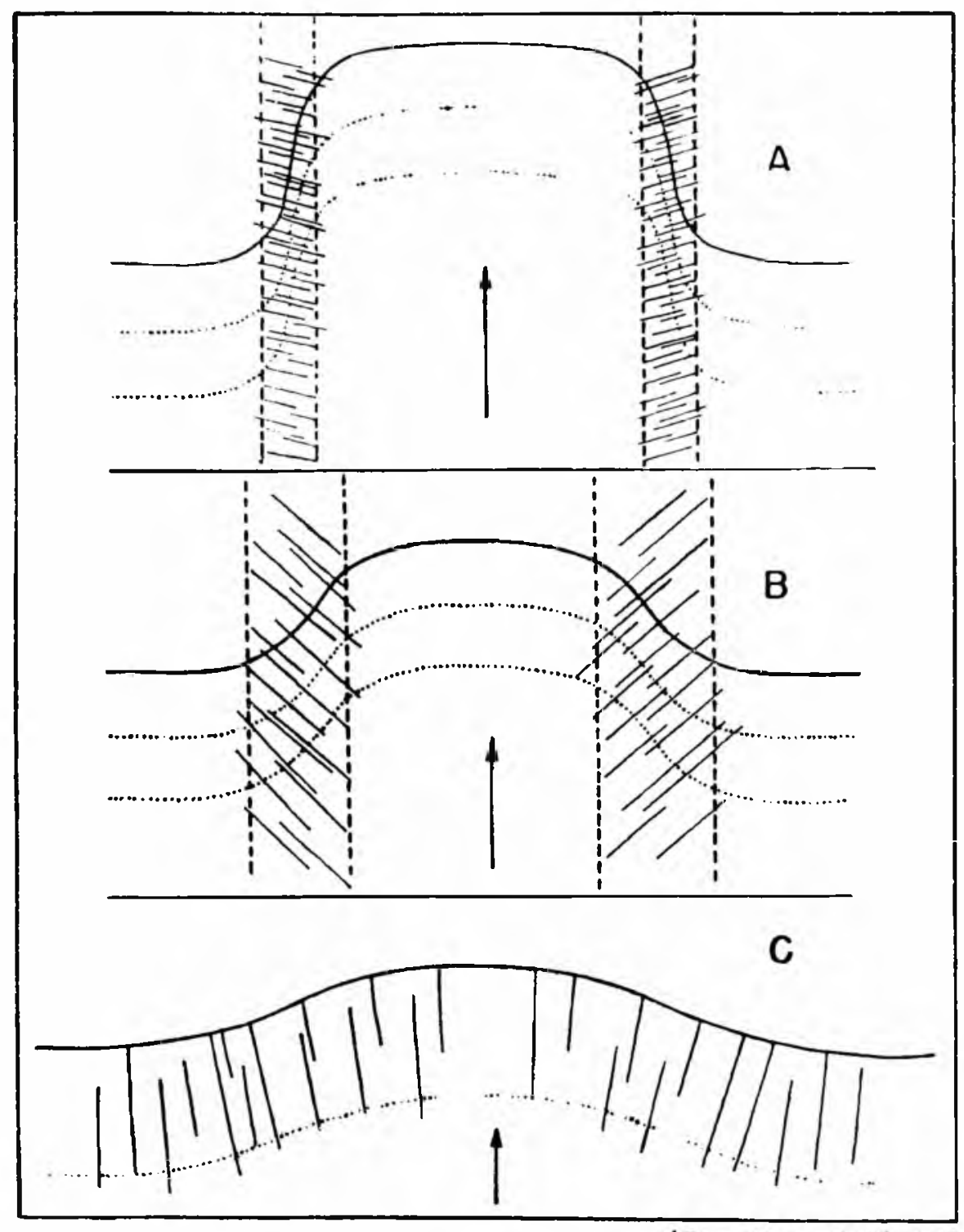

(Seg. Cloos \& Riedel)

F:g. 10 .

geométrico, seguindo os moldes traçados, as zonas fracas estariam na charneira, isto é, na borda da convexidade intrusiva, nas proximidades desta com a encaixante. Na figura 11, mostramos três perfis da borda e um teórico hipotético. Como se 
vê, a semelhança é sugestiva. Os dados relativos ao levantamento geológico parecem mostrar ter havido um soerguimento por falha. Até que ponto a interpretação é verdadeira, não sabemos.

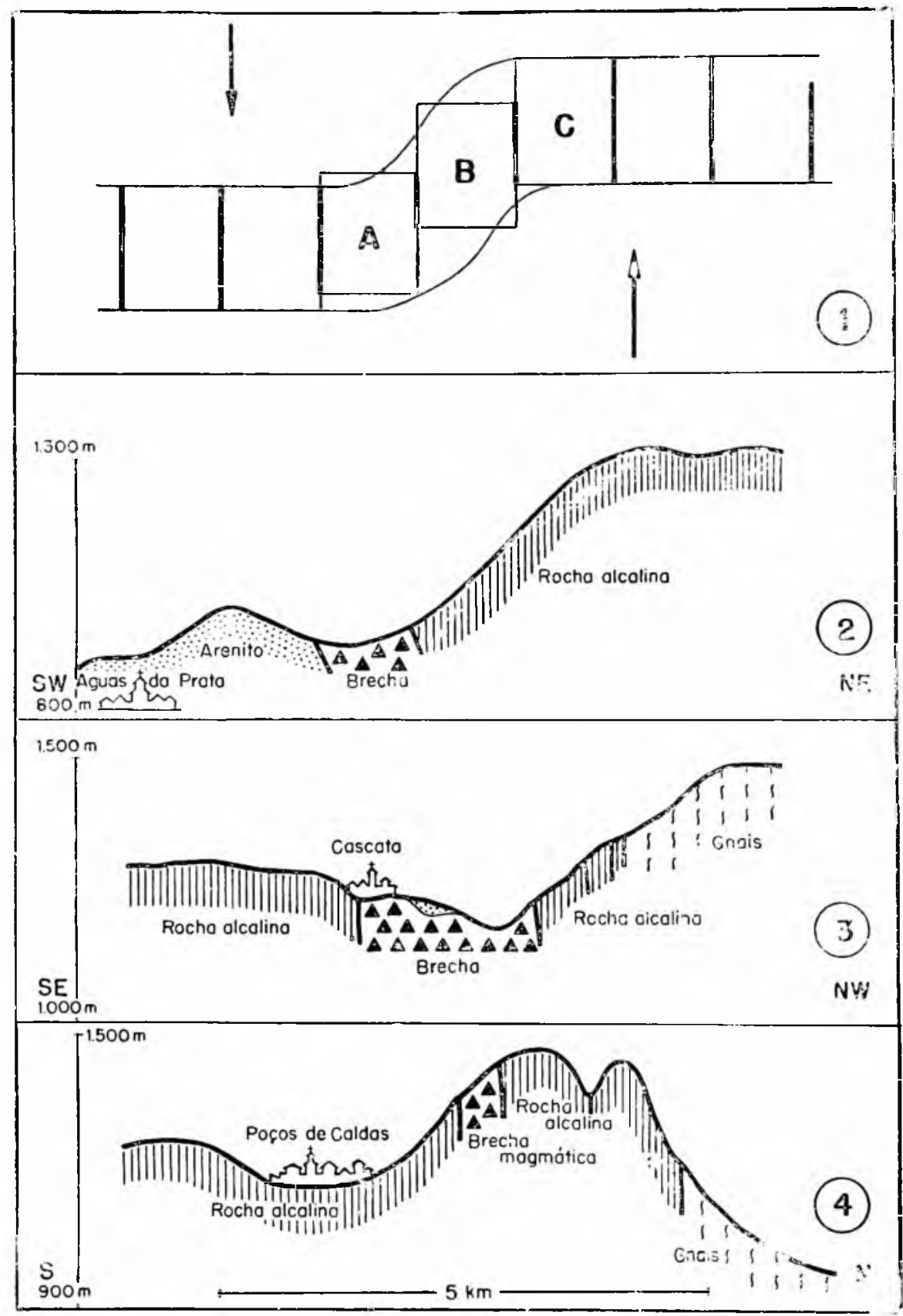

Fig. 11 .

Abatimento, erosão ou explosão? Várias hipóteses podem ser lançadas para explicar tal situação atual das rochas clásticás no planalto. 
1 - Por explosão pode ter havido o arrasamento do centro de massa intrusiva, ficando apenas alguns testemunhos do teto na beirada. Esta primeira hipótese é pouco plausível, porque exigiria uma fôrça explosiva tremenda para livrar o planalto de tôda a sua cobertura, correspondente a milhares de quilómetros cúbicos. Por outro lado, deveria haver nas vizinhanças externas, ao redor da região alcalina, blocos e material desagregado ou pulverizado resultante de tais acontecimentos, o que parece não ser o caso. Examinemos então mais duas hipóteses.

2 - Pocie ter havido um abaulamento para o exterior provocado pela intrusão, facilitando a rápida erosão dos pontos altos dessa estrutura, determinando o desaparecimento da cúpulis.

3 - Pode ter havido um abatimento do teto na parte central do planalto, determinando o englobamento do mesmo pelo magma alcalino, sem deixar vestígios na superfície.

Nada impede que logo após a intrusão ter produzido novas formas na superfície exterior, estas começassem a ser modificadas pelo trabalho da erosão. Formar-se-ia, assim, uma estrutura igual à de Poços de Caldas, arrazada no centro, onde aparecem os tipos ígneos plutônicos, e conservada na periferia, onde ainda aparecem os restos do teto, as rochas clásticas. Entretanto, existe um dado de campo que perturba êste raciocínio; trata-se da rocha provàvelmente piroclástica, que ocorre no centro sul do planalto, figura 1. Esste tufo, como vimos, está nas mesmas cotas altimétricas que o arenito da beirada (ao redor de 1.300 metros de altitude) É possivel que, depois de erodida a parte central do planalto, tivesse se depositado êsse material conseqüente de um vulcanismo ativo muito demorado no tempo geológico. Mais fácil é, porém, pensar que a causa dessa situação em igual nível das rochas clásticas no centro e na periferia, esteja ligada a um abatimento central proposta na hipótese terceira. Analisemo-la. Para haver um abatimento do teto é necessário que êste sofra um solapamento e englobamento pelo magma alcalino, em grandes ou pequenos blocos, como o tipo de "subsidence" de Billings (7, p. 286) Para que tal se 
desse, seria necessário que a possível capa, gnais e arenito, tivessem densidade maior que o magma alcalino, podendo afundar neste por gravidade. Seguindo uma tabela de Daly (15, p. 47-48), não há pràticamente diferença de densidades entre gnais e rochas alcalinas, sem contar o arenito. Este último, pelo fato de ser poroso, provàvelmente se comportaria como rocha de densidade menor Entretanto, o próprio Daly (15, pp. 47-48) se refere às rochas em alta temperatura como possuindo menor densidade que as mesmas no estado sólido, ainda frias. Além disso, essa propriedade de ter diminuida a densidade talvez se acentue em magma do tipo alcalino, rico em gases, como é o caso. De qualquer forma, o gnais não é encontrado no interior do planalto com exceção dos fragmentos constituintes dā brecha e o arenito aparece nos raros pontos em que o contacto é visível, diretamete, sôbre o magma alcalino, como se tivesse flutuado no mesmo. Além disso, como vimos, a brecha maginática encontradā no planalto, do lado interno da Serra do Paiol é uma rocha tinguaítica contendo fragmentos às vêzes angulosos de uma rocha microcristalina. Êste fato, aliado à pequena espessura dessa brecha e, ainda, sua distribuição em área, sugere ter o magma vindo até à superfície. Teria então se resfriado, quebrado e, posteriormente, sido retomado por outro avanço do magma. Se tal realmente aconteceu, o teto parece ter sido representado pela fina camada de magma solidificada. Onde estaria o teto primitivo de arenito e gnais? Teria êle se abatido no interior da massa ígnea ascendente? É difícil supor que, no caso de ter havido abatimento, não ter ficado nem um bloco na superfície, resto do antigo teto.

De qualquer forma, o abatimento, caso se tenha realizado rão deve ter sido maior que algumas dezenas de metros, puis os sedimentos mergulham pouco para o interior do planalto. Martin e Korn (26, p. 91) apontam êsse detalhe como indício de pequenos abatimentos. É preciso, no entanto, fazer uma ressalva com referência aos arenitos do norte de Andradas. Nesse local em uma faixa de algumas dezenas de metros, o arenito e siltito encontram-se dobrados, cortados por veios de quartzo e mergulhando quase na vertical. Pode-se apelar para a primeira e 
segunda hipóteses em conjunto, como solução provisória para êsses problemas, que cada uma separadamente não consegue resolver Portanto, para finalizar, podemos dizer que o pequeno r:úmero de evidências nos indicam ter havido um levantamento dos sedimentos, produzido pela rocha alcalina. Êstes devem ter-se mantido sôbre o magma alcalino. Posteriormente, a erosăo e pequeno abatimento devem ter dado ao planalto sua configuração atual, eliminando do centro o teto primitivo. Nesse lucal, manchas de tufo devem ter-se depositado, após a fase de $\epsilon$ rosão.

\section{CONCLUSŌES}

1 - Na região de Poços de Caldas, ocorrem sedimentos arenosos, siltosos e brechas vulcânicas, formando uma faixa, Junto ao contacto rocha alcalina e gnais, a 1300 metros de al. titude aproximada. A oeste da área alcalina os arenitos aparecem, capeando o gnais em uma elevação de 1580 metros de altitude. Fora dessa área não se encontrou até agora ocorrência dêsse sedimento.

2 - A análise mecân:ca revelou serem os arenitos e siltitos bem selecionados. Os coeficientes de seleção variam de 1,1 a 3,6. A média dos coeficientes de seleção é 1,7 As medianas representativas do diâmetro em milímetro dos grãos comporentes do arenito variam de 0,10 a 0,54. A grande maioria possui diâmetro de 0,3 milímetros.

3 - Quanto à forma, foi estudado o arredondamento dos componentes do arenito e siltito. A média do grau de arredondamento da fração 0,500 milímetros a 0,297 milímetros e da fração 0,074 a 0,044 milímetros, deu valores muito próximos entre si, sempre inferiores a 0,5 e superiores a 0,2 .

4 -- A análise mineralógica revela uma grande variabiliclade no teor em quartzo, de $90 \%$ a $20 \%$ nas amostras, predominando porcentagens acima de 70 . O feldspato varia em teor de 0 a $10 \%$. Os minerais argilosos, muscovita, bauerita e hidróxidos e óxidos de ferro, em conjunto variam em porcentagem de 1 a 79 Predominam as porcentagens inferiores a 30 . 
5 - Há grande variabilidade no teor de minerais pesados nos sedimentos estudados. Nunca ocorrem em quantidade superior a $1 \%$ com relação ao total de componentes. Predomina o zircão sempre presente em tôdas as amostras. Em ordem decrescente, aparecem ainda os seguintes minerais: anatásio, turmalina, rutilo, granada, monazita, hornblenda, apatita e córindon. A maior quantidade e variabilidade de minerais pesados ocorre nos sedimentos de Aguas da Prata e arenitos da Serra do Mirante, amostras de 7 a 11 . Além dêsses minerais, ocorre muito leucoxênio como cimento no arenito.

6 - Os grãos de areia, examinados em relação ao brilho, mostram-se geralmente foscos. Pelo fato do material examinado apresentar baixo grau de arredondamento, concluiu-se que os grãos foscos adquiriram êsse caráter, por corrosão.

7 - A máxima espessura alcançada pelos sedimentos é de aproximadamente 90 metros, em Aguas da Prata. Trinta metros de arenito no tôpo a 60 metros, aproximadamente, de siltito com intercalaçōes arenosas, abaixo. O material fino apresenta acamamento laminar paralelo e rítmico: quando inclinado, os ângulos são menores que $20^{\circ} \mathrm{O}$ arenito apresenta estratificação plana, paralela, ou cruzada em ângulos ao redor de $30^{\circ}$ Em certos locais, o arenito toma um fácies arcosiano, com estrutura de depósito torrencial; em outros pontos, apresenta nıveis de seixos. No planalto, falta em geral o siltito e as camadas de arenito parecem ser pouco espessas. Acham-se cortádas por intrusões alcalinas e, em certos pontos, por intrusões básicas (diabásio). As intercalações de arenito e siltito parecem indicar um ambiente misto de sedimentação aquoso e eólico com predominância final dêste último.

8 - Pelo fato de não terem sido encontrados fósseis nesses sedimentos, foi impossível datá-lo. Estabeleceu-se então uma correlação com outros sedimentos em bases litológicas. Foi feita uma comparação com sedimentos flúvio-glaciais, arenito Botucatu e Bauru. Os minerais pesados e os resultados granulométricos indicaram algumas semelhanças entre o arenito de Poços de Caldas e o arenito Botucatu, cuja correlação foi por 
nós aceita provisòriamente, atribuindo a êle idade triássica. A hipótese de se tratar de arenito Bauru foi eliminada, pelo menos em Aguas da Prata e ao norte de Andradas, pelo fato de o sedimento estar cortado pelo diabásio nesses locais.

9 - Como brechas foram classificadas as rochas fragmentúrias ligadas diretamente ao vulcanismo alcalino. Ocorrem em afloramentos, acompanhando internamente a borda montanhosa do planalto. São elas de dois tipos principais:

a - detríticas; b - magmáticas

a - Detriticas: Essa rocha ocorre de Poços de Caldas até Águas da Prata e em pequeno afloramento isolado ao norte de Andradas, na fazenda Pinheirinho. Os fragmentos dispõem-se, geralmente, de modo desorientado, em massa fina afanítica castanha ou azulada esverdeada. Os fragmentos mais comuns são de diabásio alterado e, em menor quantidade, sienito, quartzito, lava e gnais. Entre os fragmentos de minerais predomina o quartzo detrítico e feldspato, geralmente corroídos e substituídos por calcita. A matriz, isto é, o feltro da brecha, é rico em calcita, hematita, egirina e, em menor quantidade, em leucoxênio, apatita e biotita. Essas rochas aparecem acamadas em Cascata e ainda nas proximidades de Poços de Caldas, junto ac: Rio das Antas. Além dêsse tipo, existe rocha piroclástica propriamente dita, muito fina, acamada, com fragmentos de vidro e massa castanha escura, decomposta, encrinisada na tsase da Serra do Paiol e no centro do planalto. em pequeno afloramento.

b - Magmática: A matriz é tinguaitica e, portanto, de rocha ígnea alcalina, contendo fragmentos de rocha piroxênica, lava, arenito e foiaito, nas proximidades de Poços de Caldas. Na Serra do Paiol, nos limites montanhosos a oeste do planalto, essa rocha é do mesmo tipo. A matriz apresenta textura mais grosseira e os fragmentos são da mesma rocha, porém mais fina, microcristalina. Esta última brecha ocorre em area de 5 quilómetros quadrados aproximadamente e em espessura no máximo de uma dezena de metros. 
10 - Quanto à origem:

As brechas do tipo a são detríticas, primàriamente, e posteriormente, modificadas por movimento, percolação de soluções e gases. Os indícios que apoiam essa conclusão são os seguintes:

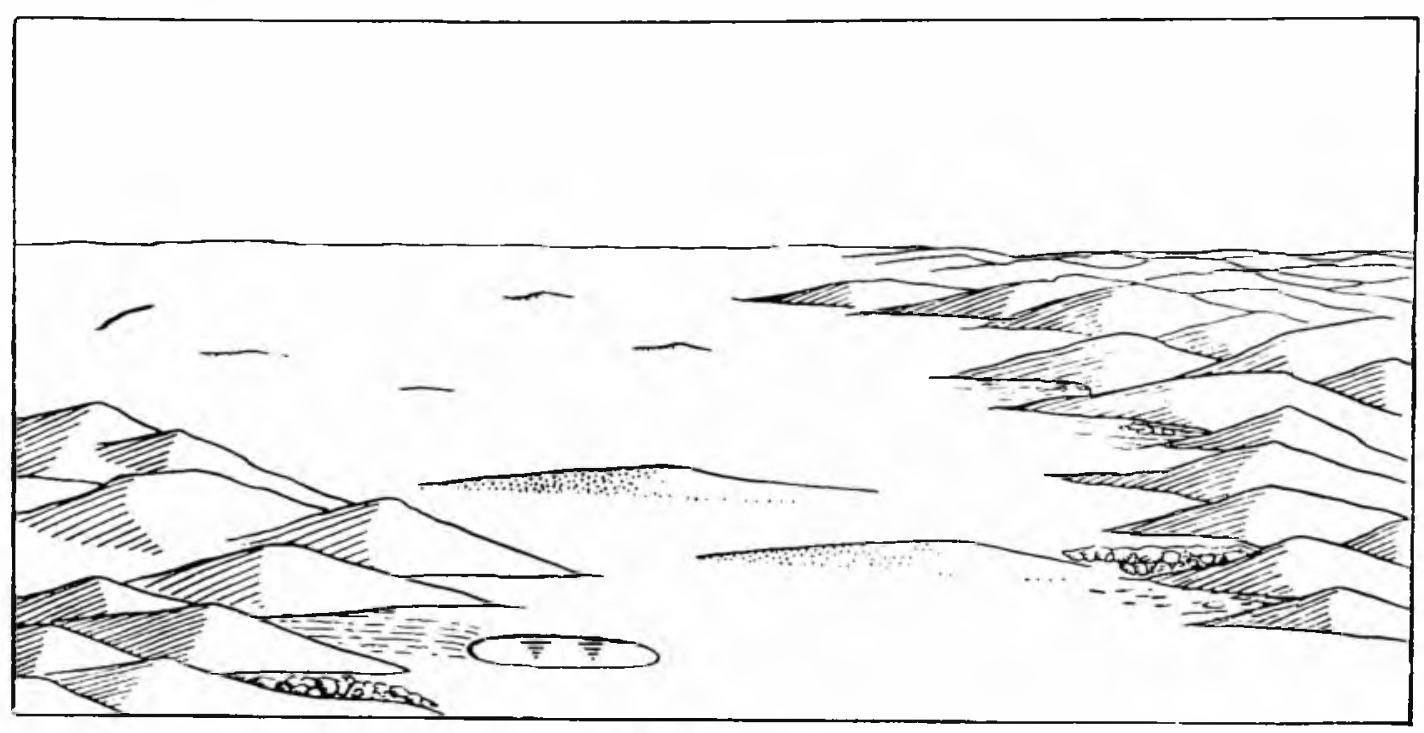

Fig. $1<$.

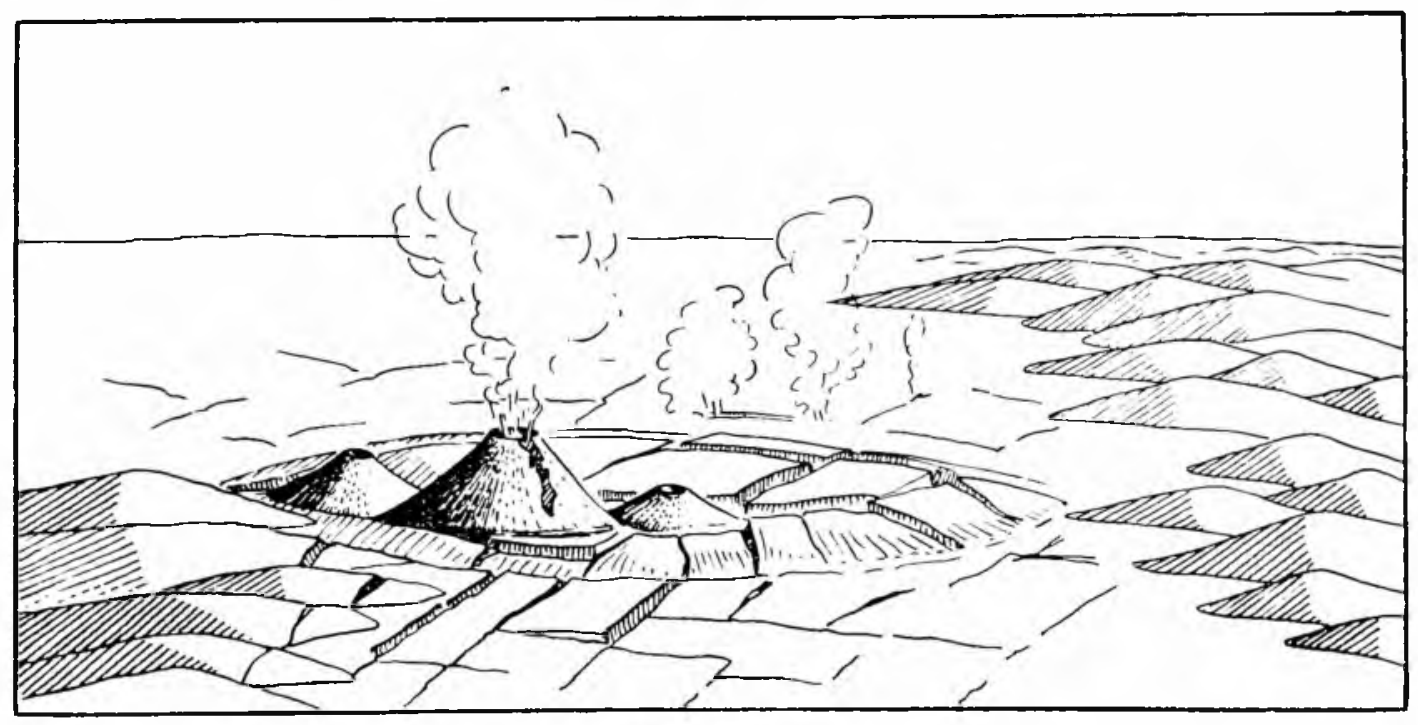

Fig. 13 .

1 - Grande quantidade de grãos de areia arredondados ria matriz.

2 - O acamamento dessas rochas em algumas exposições.

3 - A ocorrência de piroxênio sódico ideomorfo na mat.iz formando em alguns casos amídalas ou agulhas. 
4 - A albitização dos feldspatos componentes do diahásio e a corrosão dos grãos de areia.

5 - Geminação encurvada da calcita e textura "morteiro" de alguns fragmentos.

As brechas do tipo b são magmáticas, porque a matriz é de rocha ígnea (tinguaito ou lava piroxênica)

11 - As brechas são posteriores ao arenito e diabásio, no tempo, pelo fato de conterem fragmentos dessas duas rochas. Devem ser anteriores às últimas manifestações alcalinas, por estarem cortadas por diques de tinguaito.

12 - A posição dos arenitos no planalto, a 1300 metros de altitude em relaçao aos da faixa exterior a 820 metros, mostra ter havido um levantamento da área de intrusāo alcalina.

13 - O levantamento deve ter sido em bloco causado por falha, sem basculamento, porque:

1 - Os arenitos do interior e do exterior do planalto achamse de modo geral pouco perturbados em ângulo.

2 - As exposições de arenito no interior do planalto, ao longo do círculo alcalino, encontram-se aproximadamente no mesmo nível (cota de 1300 metros)

3 - O contacto das rochas alcalinas e da encaixante gnaíssica é, pràticamente, vertical.

4 - A textura fluidal do contacto das rochas alcalinas com o cristalino é, quando visível, também aproximadamente vertical.

14 -- Há alguns indícios de que o planalto tenha sofrido pequeno abatimento central. Os indícios são os seguintes:

1 - Os arenitos mergulham para o interior do planalto, de modo geral.

2 - Do lado de fora, na Serra do Mirante, o arenito está situado sôbre o gnais, em maior altitude (1580 metros) que os do planalto (1300 metros)

3 - Ocorre, no centro do planalto, uma rocha possivelmente piroclástica, em mesmo nível que os arenitos da borda inter. na do planalto. Esste último, que é o argumento mais forte, mostra que houve ou abatimento, ou o vulcanismo da região demorou-se ativo em tempo suficientemente longo, para que a de- 
posição da rocha piroclástica se desse depois da erosão ter alcançado tal nível.

15 - Com base nos dados geológicos, inferências e conjecturas; foi tentada uma representação esquemática da sucessão r,rovável de acontecimentos geológicos ocorridos na região de Poços de Caldas, figuras 12, 13, 14 e 15

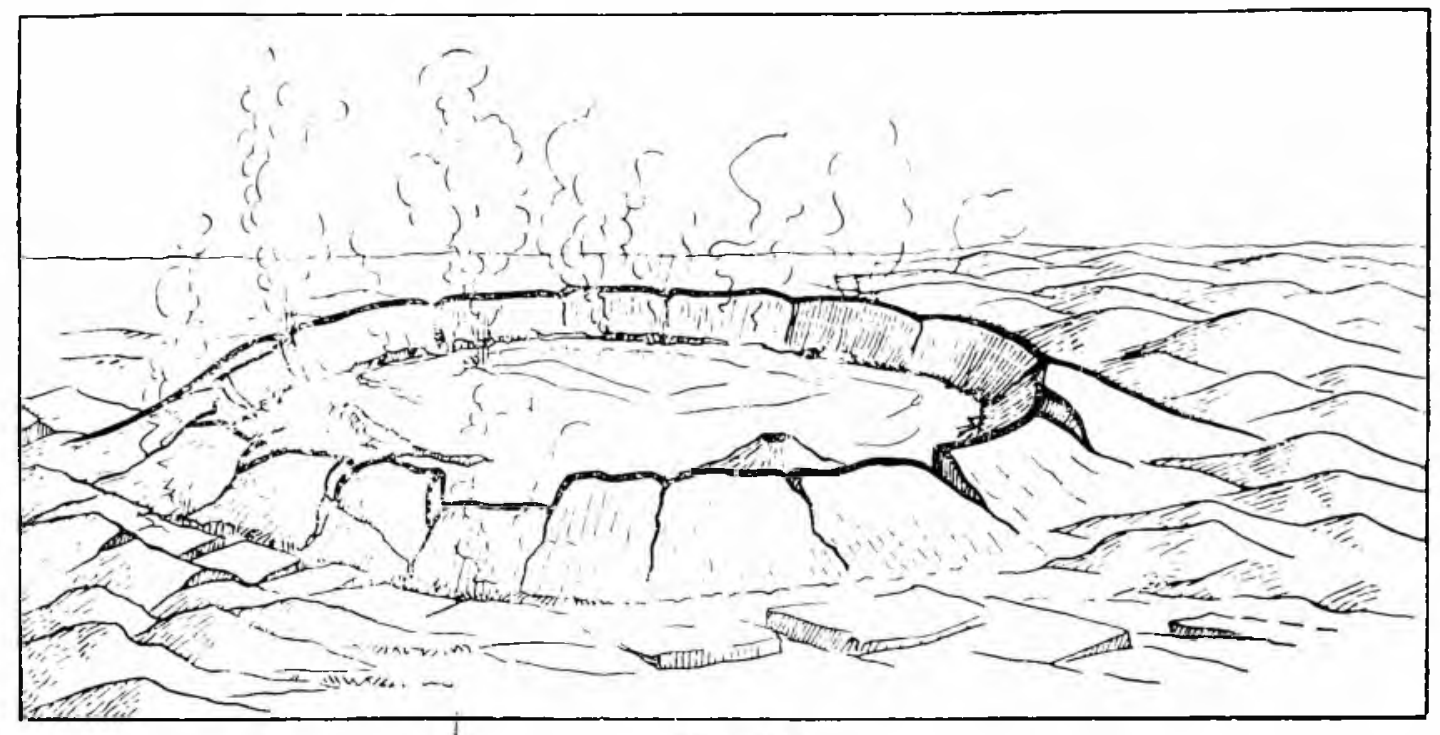

Fig. 14

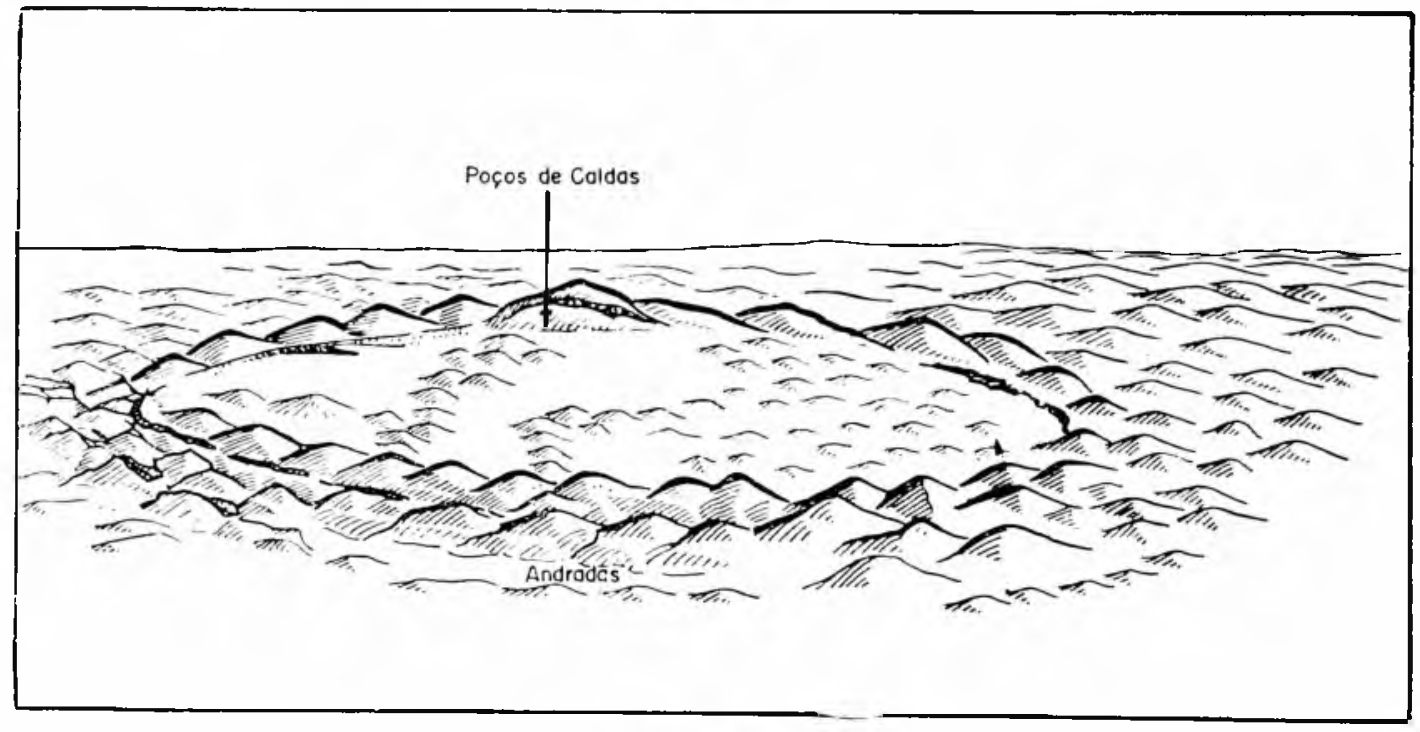

Fig 15 .

A primeira, mostra a fase anterior à intrusão, em que as areias ocuparam a região Junto às montanhas, no deserto, depositaram-se silte e argila.

A segunda figura mostra a intrusão e vulcanismo. 
A terceira figura mostra o abatimento que foi exagerado no desenho.

A quarta figura mostra, de modo esquemático, a forma atual do planalto, após longa ação erosiva.

\section{BIBLIOGRAFIA CITADA}

1 - BAGNOLD, R. A. - The physics of blown sand and desert dunes, 265 p., Methuen \& Co. Ltd., London. 1941.

2 - BALK, R. - Structural behavior of igneous rocks, 177 pp., Edw arde Brothers Inc., Michigan, 1948.

3 - BARBOSA, O. - Notas preliminares sôbre o Planalto de Poços de Caldas e suas possibilidades Econômicas, Serv. Fom., Prod. Mineral, (Brasil), Avulso 8, pp. 1-33. 1936.

4 - - Sôbre a Idade das Rochas Alcalinas e a Origem do Planalto de Poços de Caldas, Min. e Met., vol. XII, n. ${ }^{0}$ 76, pp. 235-237, Rio de Janeiro, 1948.

5 - BARREL, J. - Relations Between Climate and Terrestial Deposits, Jour. Sed. Pet., v. 21, n. 3, pp. 147-150, 1951.

6 - BARTH, T. F. W - Theoretical Petrology, John Wiley \& Sons, Inc., New York, 1952.

7 - BILlings, M. P - Structural Geology, Prentice Hall, Inc, New York, 1942.

8 - BOWEN, N. L. - The Evolution of The Igneous Rocks, Dover Pub., Inc., New York, 1956.

9 - BRAMMALL, A. e Harwood, H. F - Ocurrence of rutile, brookite, and anatase on Dartmoore, Min. Mag., n. 20, pp. 20-26, 1923.

10 - BRANCO, J. J. R. - Notas sôbre a geologia e Petrografia do Planalto de Poços de Caldas M. G., Esc. Eng. Univ., Min. Ger., Inst. Pes. Rad., n. 5, 73 p., 1956.

11 - CAilleuX, A. - Morphoskopische Analyse der Geschiebe und ihre Bedeutung für die Paläoklimatologie, Geol. Rund. v. 40 , h. 1, p. 11-19, 1952.

12 - CARvalho, A. M. V - Contribuição ao Estudo Petrográfico do Arenito Botucatu no Estado de São Paulo, Bol. Soc. Bras., Geol., v. 3, n. 1, p. 51-71, 1954.

13 - CLOOS, H. - Bau und tätigkeit von tuffschloten, Geol. Rund., v. 32, h. 1-2, p. 709-799, 1941.

$14-$ Hebung-Spaltung-Vulkanismus, Geol. Rund., v.30, p. 405-527, 1939. 
15 - DALY, R. A. - Igneous Rocks and Depths of the Earth, Mac Graw Hill Book Co., Inc., 1933.

$16 j$ - DERBY, O. A. - Sôbre aś Rochas Nefelínicas no Brasil, (Extraido), Rev., Eng., Rio de Janeiro, p. 1-15, 1888.

17 - FRANCO, R. R. e Gama, R. S. - Sôbre o Zircão de Florânia, Rio Grande no Norte, Brasil, Bol. Soc. Bras. Geol., v 4, n. 2, p. 41-49, 1955.

12 - Freitas, R. O. - As Estruturas Fósseis do Sistema de Santa Catarina no Planalto de Poços de Caldas, Bol. Assoc. Geogr. Bras., n. 3, p. 25-36, 1943.

19 - Ensaio sôbre a Tectônica Moderna do Brasil, 120., Bol. Dep. Geol. Fac. Fil. Ci. Let. de São Paulo, n.6, 1951.

20 - - Sedimentação, Estratigrafia e Tectônica da Série Bauru, (Estado de São Paulo), 185 p. Bol. Dep. Geol. Fac. Fil. Ci. Let. de São Paulo, n. 14, 1955.

21 - HAMiLTON, W. B. - Playa sediments of Rosamond Dry Lake, California, Jour. Sed. Petr., v 21. n. 3, p. 147-150, 1951 .

22 - KRUMBEIN, W C. \& Sloss, L. L. - Stratigraphy and Sedimentation, W H. Freeman \& Co. S. Francisco, 1951.

22 - KRYNINE, P D. - Arkose Deposits in the Humid Tropics. Am. Jour. Sc., ser. 5, v. 29, p. 353-363, 1935

24 - LAHEE, F H. - Field Geology, Mac Graw Hill Book Co., Inc., 1941.

25 - LEINZ, V - Estudos sôbre a glaciação Permo Carbonifera do Sul do Brasil. Serv. Fom. Prod. Min. Bol. 21, Rio de Janeiro, 1940 .

26 - MARTiN, H. e Korn, H. - The Messun Igneous Complex in South West Africa, Trans. Proc. Geol. Soc. S. Afr. v. LVII, p. 84-122, 1954.

27 - MILNER, H. B. - Sedimentary Petrography, Thomas Murby \& Co., London, 1952.

28 - PETtiJOHN, F J - Sedimentary Rocks, Harper \& Bros., New York, 1952.

29 - REICHENBACH, H. - Elements of Symbolic Logic, Mac Millan Co., New York, 1952.

30 - RUSSELL, R. D. e Taylor, R. E. - Roundness and Shape of Mississipi River Sands, Jour. Geol., vol. 45, p. 239-248, 1937

31 - SHAND, S. J. - Eruptive Rocks, John Wiley \& Sons, Inc., New York, 1943.

3̈ - SITTER, L. U. de - Structural Geology, p. 373-374, Mac Graw Hill Book Co. Inc., Michigan, 1948. 
33 - TURNER, F J e Verhoogen, J - Igneous and Metamorphic Petrology, Mac Graw Hill Book Co., 1951.

34 - TWEnHOFFEL, W. H. - Principles of Sedimentation, Mac Graw Hill Book Co. Inc., New York, 1950.

35 - UMBgrove, J. H. F - The Pulse of the Earth, Martinus Nijhoff, 1947

36 - WADDEL, H. - Volume, Shape and Roundness of Particles, Jour. Geol., v 40, p. 443-451, 1932. 


\section{Í N D I C E}

$\begin{array}{llllllllll}\text { Abstract } & \ldots & \ldots & \ldots & \ldots & \ldots & \ldots & & & \ldots\end{array}$

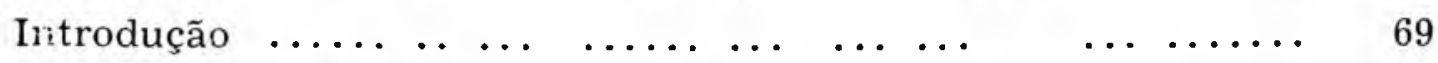

$\begin{array}{llllllll}\text { Arenitos e Siltitos } & \ldots & \ldots & \ldots & \ldots & 72\end{array}$

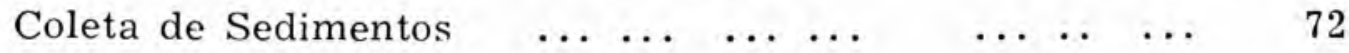

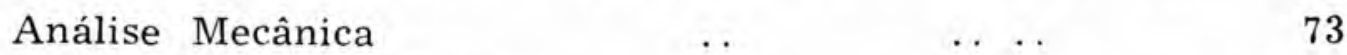

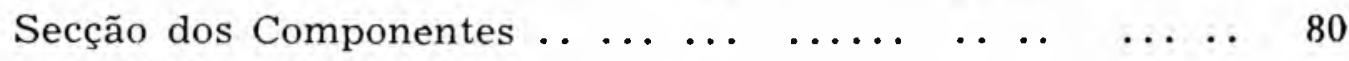

$\begin{array}{llllllll}\text { Brilho } & \ldots & \ldots & \ldots & \ldots & & & \\ & & & \ldots & & \end{array}$

Análise Mineralógica $\ldots \ldots \ldots \ldots$

$\begin{array}{lllllll}\text { Minerais Pesados } & \ldots & \ldots & \ldots & \ldots & & \end{array}$

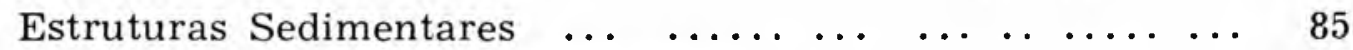

$\begin{array}{lllllll}\text { Considerações sôbre os Sedimentos } & \ldots & \ldots & & \ldots & 87\end{array}$

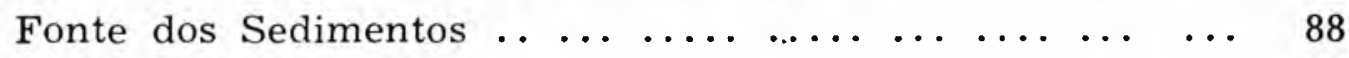

$\begin{array}{llllll}\text { Idade dos Arenitos } & \ldots & \ldots & \ldots & 89\end{array}$

$\begin{array}{lllllllllllll}\text { Brechas } & \ldots & \ldots & \ldots & \ldots & \ldots & \ldots & \ldots & \ldots & \ldots & \ldots & \ldots & \end{array}$

$\begin{array}{llllll}\text { Descrição } & \ldots & \ldots & \ldots & & 9\end{array}$

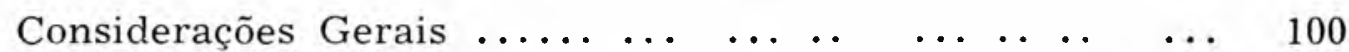

$\begin{array}{lllllll}\text { Idade das Brechas } & \ldots & \ldots & \ldots & \ldots & \ldots & 102\end{array}$

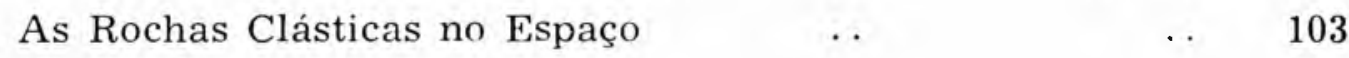

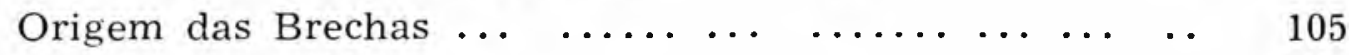

$\begin{array}{llllllll}\text { As Grandes Estruturas } & \ldots & \ldots & \ldots & \ldots & \ldots & & 109\end{array}$

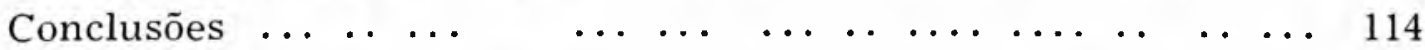

$\begin{array}{lllllll}\text { Bibliografia } & \ldots & \ldots & \ldots & \ldots & 120\end{array}$ 